\title{
The Role of Personality and Gender in Performance in Science and Engineering
}

\author{
Rossina B. Miller
}

Follow this and additional works at: https://researchrepository.wvu.edu/etd

\section{Recommended Citation}

Miller, Rossina B., "The Role of Personality and Gender in Performance in Science and Engineering" (2016). Graduate Theses, Dissertations, and Problem Reports. 6235.

https://researchrepository.wvu.edu/etd/6235

This Thesis is protected by copyright and/or related rights. It has been brought to you by the The Research Repository @ WVU with permission from the rights-holder(s). You are free to use this Thesis in any way that is permitted by the copyright and related rights legislation that applies to your use. For other uses you must obtain permission from the rights-holder(s) directly, unless additional rights are indicated by a Creative Commons license in the record and/ or on the work itself. This Thesis has been accepted for inclusion in WVU Graduate Theses, Dissertations, and Problem Reports collection by an authorized administrator of The Research Repository @ WVU. For more information, please contact researchrepository@mail.wvu.edu. 


\title{
The Role of Personality and Gender in Performance in Science and Engineering
}

\author{
Rossina B. Miller, B.S \\ Thesis submitted to the \\ Eberly College of Arts and Sciences at \\ West Virginia University \\ in partial fulfillment of the requirements for the degree of \\ Master of Science in Physics \\ John Stewart, $\mathrm{PhD}$ - Chair \\ Paul Miller, $\mathrm{PhD}$ \\ Edgar Fuller, $\mathrm{PhD}$ \\ Department of Physics and Astronomy \\ Morgantown, West Virginia \\ 2016
}

Keywords: personality; academic achievement; gender differences; STEM

Copyright 2016 Rossina B. Miller 


\begin{abstract}
The Role of Personality and Gender in Performance in Science and Engineering
\end{abstract}

\title{
Rossina B. Miller, B.S.
}

Science, Technology, Engineering, and Mathematics (STEM) student success is important to universities across the nation. Existing studies have examined standardized exams and high school GPA as predictors of student success; fewer studies have examined the role of personality. The present study examined whether STEM students have different personalities than the general population, whether population-level gender differences in personality were evident among STEM students, and if personality predicts academic success. The Big Five Inventory (BFI) measuring personality was given to a diverse population of students in introductory physics and calculus classes, as well as developmental mathematics (non-science track) classes, at a large eastern university. Science and engineering students showed similar personality characteristics to the general population; these characteristics were also similar to the developmental mathematics students. The difference in personality between genders was also similar to the general population. In the physics classes, the BFI facets' power to explain students' test averages and the course grades were moderated by gender. Personality facets, when combined with high school grade point average, had substantially different power to explain variance in course grades for male and female physics students. 


\section{ACKNOWLEDGEMENTS}

I would first like to acknowledge my thesis advisors, Gay Stewart and John Stewart. I have thoroughly enjoyed working with both of them and have appreciated their diverse views, advice, and opinions on my research. I would not have completed this thesis without their support, encouragement, and confidence in me. I would like to thank my committee members, Edgar Fuller and Paul Miller, for agreeing to be on my committee. I would also like to thank our postdoc, Rachel Stoiko, for all the help, feedback, and cookies as I was writing up my thesis. I am also grateful to all the members of my research group, Seth DeVore, Rachel Henderson, Cabot Zabriskie, Kimberly Quedado, and Lynn Michaluk without whom this research could not have been done.

Finally, I would like to acknowledge my amazing family. I would not have completed this thesis without the love, support, encouragement, smiles, and FaceTime chats from my mom and dad, Alma and Andy Miller, for their constant love and support, and for always encouraging me to pursue my interests. My sister, Claudia, for all the late nights and last minute reviews and encouraging speeches that motivated and inspired me to always be better, and kept me smiling even from a distance. Lastly, I would like to thank my friends, Brittany Johnstone, Olivia Pavlic, and Will Armentrout, for keeping me sane during graduate school. 


\section{TABLE OF CONTENTS}

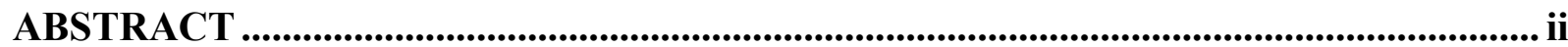

ACKNOWLEDGEMENTS................................................................................................. iii

TABLE OF CONTENTS................................................................................................. iv

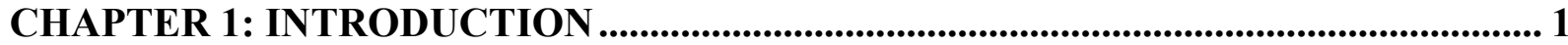

SECTION 1: PERSONALITY, GENDER, AND ACADEMIC ACHIEVEMENT ................ 1

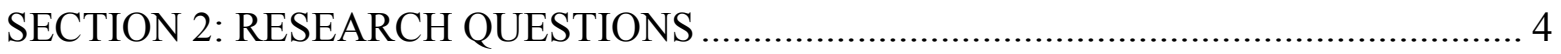

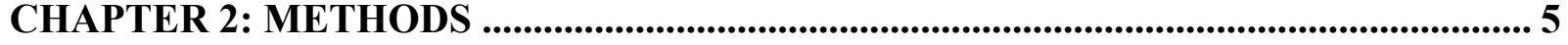

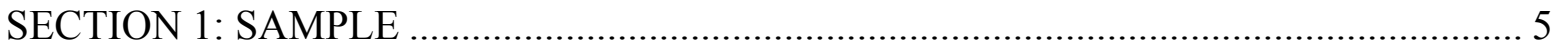

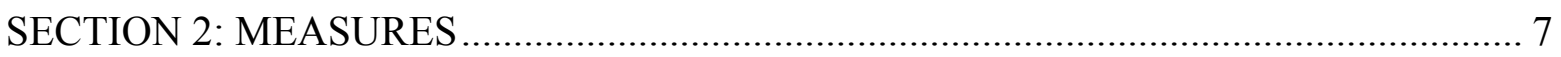

CHAPTER 3: RESULTS....................................................................................................... 8

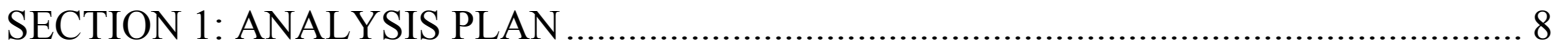

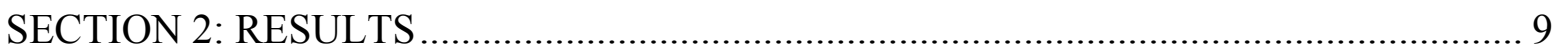

CHAPTER 4: DISCUSSION .................................................................................................. 15

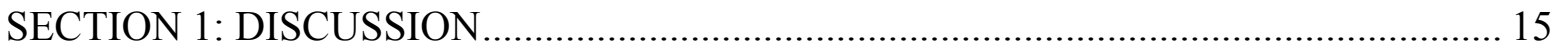

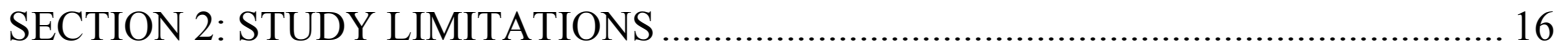

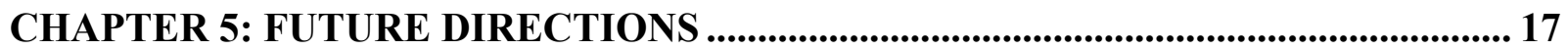

SECTION 1: THE IMPORTANCE OF LONGITUDINAL DATA ….............................. 17

SECTION 2: ADDITIONAL EXPLORATORY STUDIES..Error! Bookmark not defined.

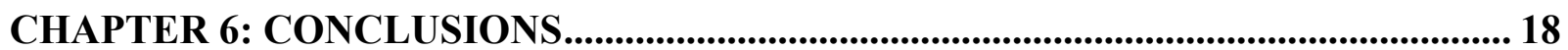

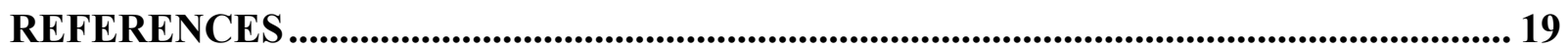

APPENDIX A: DESCRIPTIVE STATISTICS ................................................................. 24

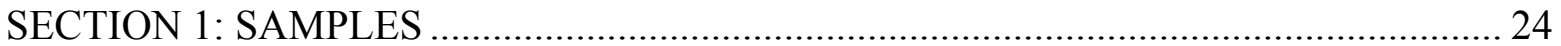

SECTION 2: DESCRIPTIVE STATISTICS OF PERFORMANCE PREDICTORS .......... 26

APPENDIX B: STATISTICAL ANALYSIS RESULTS......................................................30

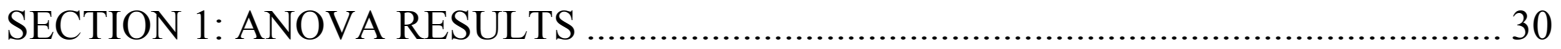

SECTION 2: HIERARCHAL LINEAR REGRESSION RESULTS.................................... 35

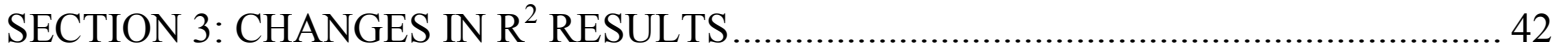




\section{CHAPTER 1: INTRODUCTION}

\section{SECTION 1: PERSONALITY, GENDER, AND ACADEMIC ACHIEVEMENT}

Individuals are characterized by their personality. When a person is being described, words such as "responsible, lively, shy, anxious, or positive" are often used. In other words, a person is described by personality traits that have persisted over time and in different situations. Understanding these traits is important as they influence the thoughts, feelings, and behaviors of an individual and can have a potential impact on learning behavior and academic achievement.

The Big Five are five dimensions used to distinguish different broad facets of human personality (Costa \& McCrae, 1985; Goldberg, 1992). The Big Five or the Five Factor Model (FFM) was developed by a number of independent researchers over the last 70 years (Digman, 1990). Known personality traits were studied and measures of these traits (via self-report and questionnaire data, peer ratings, and objective measures from experimental settings) were factor analyzed in order to find the underlying facets of personality (Allport \& Odbert,1936; Cattell, et al., 1957; Norman, 1963; Shrout \& Fiske, 1995; Tupes \& Christal, 1961). The five dimensions or facets have been defined as: openness (to experience), conscientiousness, extraversion, agreeableness, and neuroticism. Each facet contains a number of more specific, correlated subfacets. For example, extraversion is said to include such related qualities as sociability, liveliness, activity, assertiveness, sensation seeking, carefreeness, dominance, and venturesome (Matthews, et al. 2003). The five main facets are described in Table 1.

TABLE 1 - DESCRIPTION OF THE BIG FIVE PERSONALITY FACETS

\begin{tabular}{ll}
\hline Big Five Dimensions & Descriptive Facet Adjective \\
\hline Extraversion & Sociable, Assertive, Energetic, Adventurous, Positive emotions, Outgoing \\
\hline Agreeableness & $\begin{array}{l}\text { Trusting, Straightforward, Not demanding, Altruistic, Compliant, Modest, } \\
\text { Sympathetic }\end{array}$ \\
\hline Conscientiousness & $\begin{array}{l}\text { Competent, Efficient, Organized, Dutiful, Achievement striving, Self- } \\
\text { disciplined, Deliberate }\end{array}$ \\
\hline Neuroticism & $\begin{array}{l}\text { Anxious, Angry, Hostile, Depressed, Self-consciousness, Impulsive, } \\
\text { Vulnerable }\end{array}$ \\
\hline Openness & Curious, Imaginative, Artistic, Wide interests, Excitable, Unconventional
\end{tabular}

Adapted from The Big-Five trait taxonomy: History, measurement, and theoretical perspectives (John \& Srivastava, 1999). 
The initial model with five factors for personality was first identified by Donald Fiske in 1949, based on previous work by L.L. Thurstone, which had identified 66 different personality traits (reviewed in Goldburg 1993). The first model with replicable factors was found by Ernest Tupes and Raymond Christal in 1961; it contained the facets of "surgency", "agreeableness", "dependability", "emotional stability", and "culture" (Tupes \& Christal, 1961). In 1985, Costa and McCrae published the NEO personality inventory (Costa \& McCrae, 1985). In 1993, Lewis Goldberg produced the current organization of the FFM (Goldberg, 1993). These five main facets have been found to contain most known personality traits and are assumed to represent the basic structure of all personality traits (O’Conner, 2002). It is thought that the five facets have a biological basis (Pickering \& Gray, 1999), are heritable (Bouchard \& Loehlin, 2001; Johnson, McGue, \& Krueger, 2005), and are found across a number of cultures (McCrae, 2001). The FFM is compatible with other models of personality (Van Lieshout, 2000) and can be reliably assessed in adolescence (Asendorpf \& Van Aken, 2003; Costa \& McCrae, 1994; De Fruyt, Mervielde, Hoekstra, \& Rolland, 2000).

From the FFM, the Big Five Inventory (BFI) was developed and has been used to study a number of different attributes potentially influenced by personality. The BFI is a brief survey (44 questions total) designed to measure the Big Five dimensions (John et al., 1991; John et al., 2008). The effect of personality measured with the BFI (Goldberg, 1992; John et al, 1991; 2008) on academic achievement has been extensively studied (Poropat, 2009). The BFI is the most widely accepted, empirically researched, and utilized measure to understand the relation between personality and academic behaviors (O’Connor, 2002).

The present study investigated whether differences in personality are related to academic achievement in the Science, Technology, Engineering, and Mathematics (STEM) environment, including whether personality is differentially predictive of academic success for men and women. There are various barriers, internal and external, that are thought to contribute to the underrepresentation of women and other members of minority groups within STEM fields. The internalized barriers may involve career-related confidence, interests, aspirations and even personality traits (Fassinger, 2008). It has been postulated that the influence of teachers on young girls may affect their future interest in a STEM career, such that a change in teaching style could address the underrepresentation of women (Kukreti et al. 2005). Another possible influence is 
the lack of female role models in STEM careers or high-profile positions (Stout et al., 2010). This lack of role models can influence career stereotypes, such as the depiction of a scientist as an older white male, which is another potential discouragement for women wanting to enter a STEM field (Nassar-McMillan et al., 2011).

A substantial literature has sought to understand female underrepresentation in STEM fields at the college level (Beede et al., 2011; Clark Blickenstaff, 2005; Griffith, 2010; Hyde et al., 2008; Riegle-Crumb \& King, 2010; Xu, 2008). Half of the college educated workforce is comprised of women, but they hold less than a quarter of the jobs in STEM fields (Nassar-McMillan et al., 2011; Bubany et al, 2011). Research has shown patterns of gender differences on responses to the BFI, where women on average consistently report higher in neuroticism, agreeableness, warmth (an extraversion facet) and openness to feelings, while men report higher assertiveness (a facet of extraversion) and openness to ideas (Costa et al. 2001; Lippa, 2010; Schmidt et al., 2008).

A myriad of studies have investigated possible links between personality and academic achievement (Poropat, 2009). While many previous studies only looked at indices of prior academic achievement such as ACT/SAT scores or high school grade point average (HSGPA) as predictors for class performance (Hieb et al., 2015; Whalen \& Shelley, 2010), personality was suggested as a possible predictor as well (Ackerman et al., 2013; Conard, 2006). Strong links between conscientiousness and achievement were found to exist (Feist, 2012; Major et al., 2012; Korpershoek, et al., 2010; Moses et al., 2011; Poropat, 2009).

Differences in personality by gender in the general population at the traditional college age (1822 years) are well documented (Srivastava et al., 2003). The Peterson et al. (2006) study measured 468 college students in the US. The Srivastava et al. (2003) study applied the BFI to 132,000 internet users in the US and Canada and reported results by age and gender.

The current study compares personality traits of male and female college-level STEM students to the general population and investigates the relationship of these traits to academic performance. 


\section{SECTION 2: RESEARCH QUESTIONS}

This study will address the following questions.

(RQ1) Are science and engineering students' personalities different from the general population on average?

(RQ2) Are gender differences in personality found in the general population evident in a sample of STEM students?

(RQ3) Does personality predict performance in these classes?

(RQ4) Does the effect of personality on academic performance differ by gender?

(RQ5) Do personality factors provide additional explanatory power for class performance, over more common predictors of performance such as ACT/SAT scores and high school GPA? 


\section{CHAPTER 2: METHODS}

This section presents the samples and measures used in the study.

\section{SECTION 1: SAMPLE}

The BFI was given to 1,821 students from four different courses in physics and mathematics at a large university in the United States. The sample was drawn from two introductory calculusbased physics classes (P111 and P112) over two semesters (Spring and Fall 2015), as well as three introductory calculus courses (M153-155) and one mathematics course covering quantitative skill and reasoning (M112-122) in the Fall semester of 2015. The courses were the first physics and mathematics courses taken by these students: P111 covered mechanics, P112 covered electricity, magnetism, and optics, M112-122 covered a review of algebra, and M153155 covered introductory calculus. Data were gathered from four sections each of P111 and P112, 21 sections of M112, and 27 sections of M153-155.

The P111 and P112 classes consisted of a lecture and a laboratory section. In Spring 2015, P111 was taught by two instructors (I111A and I111B) with extremely different assignment and testing structures, and P112 was taught by the same instructor (I112). I111B and I1 12 used traditional assignments requiring weekly homework and examinations taken on paper; whereas, I111A required all homework submitted only at the end of the semester and used multiple-choice examinations. Each instructor constructed their own examinations.

In Fall 2015, the physics classes were dramatically restructured. Lectures were modified from 50 minutes four days a week to 50 minutes three days a week, and the labs were extended from 2 to 3 hours. The structure of the lectures was changed such that the lectures pertinent to a specific lab came before the students participated in lab. There was additional content added to labs in the form of more conceptual content and hands-on activities. P111 and P112 were each taught by two sets of two different instructors. However, efforts were made to minimize differences in class assignments. Students also took common examinations. The math courses were taught by a 
multitude of different instructors with different teaching styles. The different sections of M153155 were combined into a single course.

The students in the physics courses were pursuing the most quantitatively demanding science and engineering degrees and represented the most physical-science-oriented science and engineering majors. Majors were identified as STEM intending or non-STEM intending according to the NSF standard criteria for STEM majors. The M153-155 and M112-122 courses contained student populations that were very different. The M153-155 courses were required by majors requiring more quantitative skill, with $82 \%$ of the majors STEM intending, but including a more diverse range of majors than the physics courses. The M112-122 courses were often taken by majors requiring little mathematical skill, with only $22 \%$ of the students STEM intending. M112-122 contained a population with little STEM aspirations that may be more similar to other general population than the physics and engineering track students enrolled in P111 and P112. One can follow the development of the persistent underrepresentation of women in the physical sciences and engineering by tracking the enrollment in these classes. The distribution of women in the courses included in this study area as follows, Spring P111 was composed of 24\% women and P112 23\%, Fall P111 18\% and P112 22\%, M112-122 66\%, and M153-155 34\%. Demographic statistics are contained in Appendix A, Section 1, A5.

Introductory classes, such as those in this study, are considered gate-keeper courses, which students must pass to continue with their majors (Gasiewski, et al., 2011). Calculus and physics also have reputations for being difficult, which can also cause anxiety and affect performance (Cui, 2006; Udo et al., 2001; Udo et al., 2004). These courses offer a unique opportunity to explore the possible influence of personality and the differences in personality between the genders on class performance.

From the surveyed students who were given the BFI, four sample subsets were created, (Samples A, B, C, and D). In all samples, students who withdrew from the course (received a W) or were missing reports of their high school GPA or ACT/ SAT scores were removed. From the physics courses, students who didn't achieve a minimum grade of D were also removed. 
Sample A combined spring and fall students from the physics courses to form an overall sample. In cases of duplicate data points, from students taking P111 in the spring and then P112 in the fall, the BFI and physics grade scores were averaged over the two semesters. This reduced the original total of physics students from 930 surveyed students to 765 . Sample B combined physics students across semester, but separated by course (P111 N=323, P112 N=277). Duplicate students were removed altogether in order to prevent the data from being skewed. Sample C contained the full cohort of surveyed physics students, separated by semester and then by course (Spring P111 N=296, Spring P112 N=192, Fall P111 N=197, Fall P112 N=245). Sample D contained all surveyed math students from M112-122 (N=387) and M153-155 (N=669), separated by semester and then by course. Sample descriptive statistics are contained in Appendix A, Section 1, A1-4.

\section{SECTION 2: MEASURES}

Student performance was measured by course letter grade. Course grades for all four courses were converted to a numeric scale by recoding "A" to 4 , "B" to 3 , etc. Student ability was measured by ACT and SAT percentile and high school GPA (HSGPA). Verbal and mathematics $\mathrm{ACT} / \mathrm{SAT}$ scores were converted to a percentile scale. The percentiles from both ACT and SAT were combined, with the ACT reading score used as a surrogate for the SAT verbal score which produced two variables, ACT/SAT Math Percentile and ACT/SAT Verbal Percentile. Descriptive statistics for these variables are presented in Appendix A, Section 3, Tables A6-9.

Personality was measured using the BFI. The survey was administered online and took approximately 10-15 minutes to complete. Students were incentivized to participate in the survey with the offer of class credit upon completion. The averages for each facet were calculated according to the rubric associated with the BFI (John et al., 1991; John et al., 2008). 


\section{CHAPTER 3: RESULTS}

This section presents the analysis plan followed by the results.

\section{SECTION 1: ANALYSIS PLAN}

To answer the research questions posed, a series of statistical analyses were performed on Samples A, B, C, and D. The analyses are explained in detail below.

To compare the BFI results to more general populations, the results of the surveyed students from Sample A, all four physics courses, were averaged together. An overall (all students from Sample A) average of each facet was compared to the overall BFI averages of the Peterson study (Peterson et al., 2006). Within the present sample, the BFI subscale averages (overall and by gender) of the physics courses were compared to those of the mathematics courses. An analysis of variance (ANOVA) was utilized to determine if the differences in means were statistically significant.

To compare the BFI results by gender, the results of the surveyed students from Sample A and M112-122 from Sample D were averaged together. The results of Sample A, split by gender, were compared to the overall BFI averages of the Srivastava study (Srivastava et al., 2006). Within the present sample, the BFI results of female and male students in the physics courses were compared to those in the M112-122 course. These comparisons were done with an ANOVA with the results of this analysis presented in Appendix B, Section 1, Tables B1-10.

To investigate the influence of personality on academic achievement, a set of hierarchal linear regression (HRL) analyses were performed. Variables were added to produce a sequence of nested models. The statistical significance of each progressive model was tested with ANOVA. Model 1 tested the effects of ACT/SAT math and verbal percentile scores on physics grade. Model 2 tested the effects of the Big Five subscale scores (O, C, E, A, N) on physics grade. Model 3 tested the effect of HSGPA on physics grade. Model 4, built on Model 3, added ACT/SAT math and verbal percentiles to HSGPA as predictors of physics grade. Model 5 added onto Model 1, including the Big Five subscale scores to ACT/SAT math and verbal percentiles 
as predictors of physics grade. Model 6 added to Model 3, adding the Big Five subscale scores to HSGPA as predictors of physics grade. Finally, Model 7 included all of the study variables (ACT/SAT math and verbal percentiles, HSGPA, and the Big Five subscale scores) as predictors of physics grade.

While increases in the variance in physics grade accounted for by the predictors $\left(\mathrm{R}^{2}\right)$ were observed as the models progressed, the statistical significance of these increases needed to be tested. $\Delta \mathrm{R}^{2}$ is the change in $\mathrm{R}^{2}$ values from one model to another, resulting from the addition of a predictor, or set of predictors, to the regression equation. Statistical analysis was run on $\Delta \mathrm{R}^{2}$ between comparable models (i.e. Model 1 to Model 5, Model 3 to Model 6, Model 4 to Model 7, etc.) to determine whether the changes were significant.

\section{SECTION 2: RESULTS}

Appendix A, Section 3 present the average BFI scores for the classes studied both overall and disaggregated by gender. Table A10 presents the overall averages aggregated, the M112-122 courses, the results of the Srivastava 2003 study and the Peterson 2006 study.

Published measurements of the BFI facets of college age individuals from the Peterson study (Peterson et al., 2006) were compared to the BFI means from our study for the four measured courses. The students in all classes in this study demonstrated a similar pattern of personality measures as those in the other studies of American college age students (Peterson et al., 2006, Srivastava et al., 2006). While some differences were identified, these differences were in general small.

Established personality patterns which show pronounced gender differences for the neuroticism facet but small differences in other factors (Srivastava et al., 2003) were compared to the BFI results of our survey to determine if the same patterns existed for STEM students. The values presented result from interpreting the graphs in the publication and converting back to the 5point scale. The difference between the classes was analyzed by gender across the samples A, B, $\mathrm{C}$, and D. The results of this analysis is presented in Appendix B - Section 3. 
Examining Table A10 shows that for Sample A (all physics students) in this study, the BFI means show that the female students scored higher in all of the Big Five personality traits; however, subsequent ANOVA analyses of these scores demonstrate that the differences for conscientiousness, neuroticism and agreeableness were the only traits that were statistically significant between male and females. The M112-122 students showed the same personality patterns as the physics students; the only significant difference between genders was that women tested higher in neuroticism than men.

Focusing on the physics students and disaggregated by course, changed the results somewhat, but in general the difference in neuroticism between men and women was consistently the most pronounced feature. This result can be found in Table A11. For the P111 course, the BFI means show that the female students scored higher in all of the Big Five, but only the differences for conscientiousness and neuroticism were statistically significant. For the P112 course, female students scored higher than male students in everything but openness. Only the differences in neuroticism and extraversion were found to be statistically significant.

Separating the physics courses by semester showed more variation as shown in Table A12. For the Spring P111 course, the BFI means showed that the female students scored higher in conscientiousness, agreeableness, and neuroticism, had an equivalent score for openness, and scored lower on extraversion. Table B5 showed that only the difference in neuroticism was statistically significant. In the Spring P112 course, female students scored higher than male students in everything but openness. None of the differences were found to be statistically significant, as shown in Table B6. For the Fall P111 course, female students scored higher than male students in all the BFI facets, with the differences in conscientiousness and neuroticism statistically significant as shown in Table B7. For the P112 course in the Fall, female students again scored higher in all facets, but the only statistically significant difference was found in neuroticism as shown in Table B8. 
In Fall 2015, data for mathematics courses (M112-22 and M153-55) was also available and can be found in Table 13. In the M112-122 courses, the BFI means show that female students scored higher in conscientiousness, agreeableness, and neuroticism, but lower on extraversion and openness. Only the differences in agreeableness and neuroticism were statistically significant as shown in Table B9. In the M153-155 courses, the BFI means show that the female students showed the same pattern as that found in the M112-122 courses. However, as seen in Table B10, the differences in conscientiousness and neuroticism were statistically significant in this subset.

Overall, a consistent pattern of differences in neuroticism for females and males was found. While other variables were different for some samples, no other consistent differences were identified. As such, the primary difference between males and females in the general population was replicated in the college classes.

We were also interested in examining whether or not personality predicts performance in introductory physics courses. To test this relation, HLRs were performed on samples A, B, and C. In Appendix B, Section 2 presents the results of the HRLs and Section 3 presents the summaries of the changes in $R^{2}\left(\Delta R^{2}\right)$ for each sample.

In Sample A, the aggregated physics courses, we found the previously established relation between standard predictors of academic performance (ACT/SAT math and verbal percentiles and HSGPA) and class grade, Model 4 (HSGPA, ACT/SAT Math and Verbal percentile) accounted for $21 \%$ of the variance in the data. The addition of the personality facets increased the amount of variance explained, from $21 \%$ to $24 \%$. Only the conscientiousness facet was statistically significant regressor as seen in Table B11.

To more closely examine the Sample A findings, Sample B students disaggregated by semester were analyzed. We found that in splitting the courses slightly different predictors proved to be significant. In Table B12, for the P111 students, Model 4 accounted for $20 \%$ of the variance in the data with only HSGPA and ACT/SAT Math percentile proving significant. Adding personality, again with only conscientiousness being significant, increased the variance to $22 \%$. For the P112 students, the Model $4 \mathrm{R}^{2}$ was $26 \%$. While HSGPA stayed significant, in this model, 
ACT/SAT Verbal percentile proved more significant than ACT/SAT Math percentile. Model 7 (which contained all the variables) increased the variance to $29 \%$, but with only HSGPA and conscientiousness being significant.

Upon further disaggregation of the courses into Sample C (physics students disaggregated by semester and course), the predictive power of conscientiousness only appeared in the Spring P111 and P112 courses and the Fall P112 course. Additionally, HSGPA was the the only other significant predictor in Model 7 for the Spring P111, P112 and Fall P111 courses as seen in Table B14.

The effects of gender and personality on academic achievement was also explored. By disaggregating samples A, B, and C by gender, a slightly different story began to emerge from the data; the predictive power of conscientiousness remained significant only for men. For women, HSGPA was the most significant predictor of performance.

Upon review of all the physics students (Sample A) as seen in Table B11, HSGPA was a highly statistically significant $(p<0.001)$ predictor for female students' physics grade, accounting for 31 percent of the variance in the data. ACT/SAT math percentile was less significant $(p<0.05)$ predictor. Model 1 combined ACT/SAT math percentile with ACT/SAT verbal percentile accounted for $22 \%$ of the variance in the data. For male students, initially HSGPA, ACT/SAT math and verbal percentiles, and conscientiousness were significant predictors for physics grade, in the respective models. Upon combining these three variables into one model (Model 7), only ACT/SAT math percentile remained significant alongside HSGPA and conscientiousness. The combination of all the variables into Model 7 accounted for $22 \%$ of the variance in the data. When looking at the changes in the $\mathrm{R}^{2}$, it was found that only for the male students was it significant to add in personality to the regression models shown in Table B17.

When disaggregating by semester, as shown in Table B13, female students in P111 continued to follow the same pattern of HSGPA proving to be a most significant predictor across models. In P112 however, Models $1\left(\mathrm{R}^{2}=40 \%\right)$ and $5\left(\mathrm{R}^{2}=44 \%\right)$ showed that ACT/SAT math percentile were significant when HSGPA wasn't included. Models $4\left(\mathrm{R}^{2}=56 \%\right)$ and $7\left(\mathrm{R}^{2}=57 \%\right)$ showed 
that, when combined with HSGPA, ACT/SAT verbal percentile instead of ACT/SAT math percentile was significant. Tables B18-19 shows that adding in personality to the models was not statistically significant for the female students in either course. For P111 male students, the HRL analyses showed that the variables ACT/SAT math percentile in Model 1, conscientiousness in Model 2, and HSGPA in Model 3 were highly significant. In Model 5, both ACT/SAT math percentile and conscientiousness were significant. In Model 6, HSGPA and conscientiousness were significant. Model 7 showed all three of these variables as being statistically significant. However, as seen in Table 18, the changes in the $\mathrm{R}^{2}$ showed that the addition of personality variables was only significant when adding the personality facets to ACT/SAT math and verbal percentiles. For P112 male students, HSGPA, ACT/SAT math and verbal percentiles, and conscientiousness were significant in Models 1, 2, and 3 respectively. In Model 6, only ACT/SAT math percentile and conscientiousness were significant predictors; however, in Model 7 , this changed to HSGPA and conscientiousness. When looking at the changes in the $\mathrm{R}^{2}$, shown in Table B19, the addition of personality to models 1, 3, and 4 proved to be statistically significant.

When analyzing Sample C, all the students disaggregated by semester, course, and gender, HSGPA still showed to be the most significant predictor for female students course performance (as shown in Table B15) with the addition of personality not adding any predictive power as shown as Tables B20-23. In Table B16, for Spring P111 male students HSGPA and conscientiousness proved to be the most significant predictors of performance. In Table B20, the changes in $\mathrm{R}^{2}$ show that the addition of personality provided a statistically significant change in the models. Also in Table B16 male students in Spring P112, Model 3, HSGPA accounted for a statistically significant $12 \%$ of the variance in the data. When looking at Model 5, only conscientiousness was significant. In Model 6, even with the addition of personality, only HSGPA was found to be significant with $\mathrm{R}^{2}$ equaling $25 \%$. Model 7 showed the same result as Model 5, with only conscientiousness being significant. Adding personality to each of the models proved to be statistically significant, as shown in Table B21.

In Table B16, for Fall P111 male students, HSGPA was highly statistically significant in Model 3. Table B22 showed that it was not statistically significant to add personality to the models. For 
Fall P112 male students, only HSGPA was highly statistically significant in models 3, 4, 6, and 7 , but ACT/SAT math percentile was significant $(p<0.01)$ in models $1,4,5$, and 7 . It is interesting to note that for the Fall P112 male students, neuroticism actually showed to be more significant than conscientiousness; however, when looking at the changes in the $\mathrm{R}^{2}$, shown in Table B23, it was not statistically significant to add personality to the models.

To summarize, when all physics students are combined conscientiousness proved to add a statistically significant contribution in predicting physics grade. In disaggregating by gender, conscientiousness only had predictive power for male students. For female students in all samples, HSGPA was the strongest and most significant predictor of academic success. Upon disaggregating by semester and course, conscientiousness was a predictor for male student success only in the Spring courses; however, this was not the case in the Fall. 


\section{CHAPTER 4: DISCUSSION}

\section{SECTION 1: DISCUSSION}

[RQ1] Are STEM students' personalities different from the general population?

The results of our study show that on average there is no difference between in the patterns of personality of STEM students and the general population. General stereotypes of the portrayal of STEM students as different in personality exist due in part to representations in popular media. Lounsbury et al's (2012) study of working scientists suggests this stereotype is not true; the study found significant differences between scientists and workers in other occupations, but with small effect sizes. This research further confirms that personality traits do not differ between STEM students and the general student population.

[RQ2] Do gender differences in personality found in the general population persist in science classes?

We found that on average female students displayed the higher levels of neuroticism than men, as do females in a more general population. This result was consistent across all the samples.

[RQ3] Does personality predict performance in these classes?

When looking at personality as a predictor for academic achievement, it should be noted that it had a strong effect in the Spring course but not in the Fall. When looking at Sample A (all physics students) and Sample B (physics students disaggregated by course) this effect was also seen, but likely was influenced by the strong effect observed in the Spring. In the Fall, personality seemed to play less of a role in predicting academic performance. The difference between the spring and fall results could be due to the restructuring of the physics courses.

[RQ4] Does the effect of personality on academic achievement differ by gender? 
The results of the analyses indicate that the effect of personality on academic achievement differs greatly by gender. For female students, personality was not a predictor of academic achievement. Conscientiousness for male students was highly significant in predicting physics grade.

It may be worthwhile to consider that the role that conscientiousness played in predicting male academic achievement was not seen in women because this trait may have been factored in at an earlier educational stage for female students. It may be possible that conscientiousness may have been a stronger contributing factor for female students at the high school level; therefore, the personality facets' effects on course grades were already contained in the female HSGPA.

[RQ5] Do personality factors provide additional explanatory power for class performance, over more common predictors of performance such as ACT/SAT scores and high school GPA?

When looking at the individual courses, personality only provided more information in the Spring. When pooling both spring and fall semesters, such as samples A and B, the results supported that the proposed hypothesis that personality was statistically significant in predicting physics grade.

\section{SECTION 2: STUDY LIMITATIONS}

There are issues with measuring an unstable construct such as personality, because it is known to change over time. The gender differences in personality are also known to change over the course of time (e.g., Twenge 2001a and 2001b). Previous research also found that personality becomes less predictive later in students' tenure at the university (Martin et al., 2006).

Additional limitations to this study include the change in physics course structure. Since the Spring and Fall semester courses were so radically different, there may be undue influences on the results when the semesters were pooled together. This could be resolved with a more longitudinal study, incorporating more semesters. 


\section{CHAPTER 5: FUTURE DIRECTIONS \\ SECTION 1: THE IMPORTANCE OF LONGITUDINAL DATA}

The results of the data gathered in two semesters clearly show additional data is needed. For example, had just the Spring semester been analyzed the data would have shown that personality played a significant predictor of academic performance. Samples A and B, which contained Spring and Fall semesters, were possibly skewed towards showing that personality predicted academic performance to a larger degree than would be thought when considering the results of analyzing sample C. Data across more semesters would either decrease this effect or give a clearer picture of the relation between personality and academic performance. Additionally, given the changes in class structure from the Spring to Fall, additional semesters with the same course setup would strengthen the data and give more accurate results. 


\section{CHAPTER 6: CONCLUSIONS}

This study set out to determine if a link exists between academic achievement and personality traits in STEM students. Furthermore, we investigated whether differences in personality traits between genders were a factor in predicting academic achievement. This was in part, an effort to try to understand the underrepresentation of women in STEM fields. To answer these questions, the Big Five Inventory measuring the 5-factor personality model was given to a diverse population of students in introductory physics and calculus classes, as well as developmental mathematics (non-science track) classes, at a large eastern university. Our results suggest that there is no difference between STEM students' personalities and those of the general population. The personality patterns of females and males were the same between the general population and STEM students. Although our results show that personality predicts academic achievement, this effect disappears when the samples are broken down by class and semester. When split by gender, our results show that of the five personality traits, conscientiousness was the sole significant predictor for male students; whereas, academic performance of the female students was not predicted by personality. Lastly, our data revealed that including personality, with the more common predictors of academic performance (ACT/SAT and HSGPA), had a significant effect on predicting physics grade. Altogether our results show that it might be beneficial to consider personality traits when evaluating students for course placement and trying to predict their future academic performance. 


\section{REFERENCES}

Ackerman, P. L., Kanfer, R., Beier, M. E. (2013). Trait complex, cognitive ability, and domain knowledge predictors of baccalaureate success, STEM persistence, and gender differences. Journal of Educational Psychology, 105(3), 911.

Allport, G. W., Odbert, H. S. (1936). Trait-names: A psycho-lexical study. Psychological monographs, 47(1), i.

Benet-Martinez, V., John, O. P. (1998). Los Cinco Grandes across cultures and ethnic groups: Multitrait multimethod analyses of the Big Five in Spanish and English. Journal of Personality and Social Psychology, 75, 729-750.

Beede, D. N., Julian, T. A., Langdon, D., McKittrick, G., Khan, B., Doms, M. E. (2011). Women in STEM: A gender gap to innovation. Economics and Statistics Administration Issue Brief, (04-11).

Bieri Buschor, C., Berweger, S., Keck Frei, A., Kappler, C. (2014). Majoring in STEM-What Accounts for Women's Career Decision Making? A Mixed Methods Study. The Journal of Educational Research, 107(3), 167-176.

Cattell, R. B. (1957). Personality and motivation structure and measurement. Oxford, England: World Book Co.

Clark Blickenstaff, J. (2005). Women and science careers: leaky pipeline or gender filter? Gender and education, 17(4), 369-386.

Conard, MA (2006). Aptitude is not enough: How personality and behavior predict academic performance. Journal of Research in Personality, 40,339-346.

Costa, P. T., McCrae, R. R. (1985). The NEO personality inventory. 
Costa Jr, P., Terracciano, A., McCrae, R. R. (2001). Gender differences in personality traits across cultures: robust and surprising findings. Journal of personality and social psychology, 81(2), 322 .

Cui, L. (2006). Assessing college students' retention and transfer from calculus to physics. ProQuest Information and Learning Company.

Digman, J. M. (1990). Personality structure: Emergence of the five-factor model. Annual review of psychology, 41(1), 417-440.

Feist, G. J. (2012). Predicting interest in and attitudes toward science from personality and need for cognition. Personality and Individual Differences, 52(7), 771-775.

Gokhale, A. A., Rabe-Hemp, C., Woeste, L., Machina, K. (2015). Gender Differences in Attitudes Toward Science and Technology Among Majors. Journal of Science Education and Technology, 24(4), 509-516.

Goldberg, L. R. (1992). The development of markers for the Big-Five factor structure. Psychological assessment, 4(1), 26.

Goldberg, L. R. (1993). The structure of phenotypic personality traits. American psychologist, $48(1), 26$.

Griffith, A. L. (2010). Persistence of women and minorities in STEM field majors: Is it the school that matters?. Economics of Education Review, 29(6), 911-922.

Hall, C. W., Kauffmann, P. J., Wuensch, K. L., Swart, W. E., DeUrquidi, K. A., Griffin, O. H., \& Duncan, C. S. (2015). Aptitude and personality traits in retention of engineering students. Journal of Engineering Education, 104(2), 167-188. 
Hieb, Jeffrey L., et al. "Predicting performance in a first engineering calculus course: implications for interventions." International Journal of Mathematical Education in Science and Technology 46.1 (2015): 40-55.

Hyde, J. S., Lindberg, S. M., Linn, M. C., Ellis, A. B., \& Williams, C. C. (2008). Gender similarities characterize math performance. Science, 321(5888), 494-495.

John, O. P., Naumann, L. P., Soto, C. J. (2008). Paradigm Shift to the Integrative Big-Five Trait Taxonomy: History, Measurement, and Conceptual Issues. In O. P. John, R. W. Robins, \& L. A. Pervin (Eds.), Handbook of personality: Theory and research (pp. 114-158). New York, NY: Guilford Press.

John, O. P., Donahue, E. M., Kentle, R. L. (1991). The Big Five Inventory--Versions 4a and 54. Berkeley, CA: University of California,Berkeley, Institute of Personality and Social Research.

John, O. P., Srivastava, S. (1999). The Big-Five trait taxonomy: History, measurement, and theoretical perspectives. In L. A. Pervin \& O. P. John (Eds.), Handbook of personality: Theory and research (Vol. 2, pp. 102-138). New York: Guilford Press.

Komarraju, M., Nadler, D. (2013). Self-efficacy and academic achievement: Why do implicit beliefs, goals, and effort regulation matter?. Learning and Individual Differences, 25, 6772.

Korpershoek, H., Kuyper, H., Bosker, R., van der Werf, G. (2013). Students leaving the STEM pipeline: An investigation of their attitudes and the influence of significant others on their study choice. Research Papers in Education, 28(4), 483-505.

Kukreti, A. R., Islam, S., Oerther, D. B., Davis, K., Turner, M. G., Maltbie, C., Fowler, T. W. (2005). Investigating Student Interest in Post-Secondary STEM Education. age, 10, 1. 
Laguador, J. M. (2013). Students' Interest in Engineering and Average Final Grade in Mathematics as Factors in Program Retention. IAMURE International Journal of Multidisciplinary Research, 5(1).

Lippa, R. A. (2010). Gender differences in personality and interests: when, where, and why? Social and Personality Psychology Compass, 4(11), 1098-1110.

Major, D. A., Holland, J. M., Oborn, K. L. (2012). The influence of proactive personality and coping on commitment to STEM majors. The Career Development Quarterly, 60(1), 1624.

Moses, L., Hall, C., Wuensch, K., De Urquidi, K., Kauffmann, P., Swart, W., Duncan, S., Dixon, G. (2011). Are Math Readiness and Personality Predictive of First-Year Retention in Engineering? The Journal of Psychology, 145(3).

Nassar-McMillan, S. C., Wyer, M., Oliver-Hoyo, M., Schneider, J. (2011). New tools for examining undergraduate students' STEM stereotypes: Implications for women and other underrepresented groups. New Directions for Institutional Research, 2011(152), 87.

Norman, W. T. (1963). Toward an adequate taxonomy of personality attributes: Replicated factor structure in peer nomination personality ratings. The Journal of Abnormal and Social Psychology, 66(6), 574.

Riegle-Crumb, C., King, B. (2010). Questioning a white male advantage in STEM examining disparities in college major by gender and race/ethnicity. Educational Researcher, 39(9), 656-664.

Rubinstein, G. (2005). The big five among male and female students of different faculties. Personality and Individual Differences, 38(7), 1495-1503. 
Schmitt, D. P., Realo, A., Voracek, M., Allik, J. (2008). Why can't a man be more like a woman? Sex differences in Big Five personality traits across 55 cultures. Journal of personality and social psychology, 94(1), 168.

Shrout, P. E., Fiske, S. T. (1995). Personality research, methods, and theory.

Srivastava, S., John, O. P., Gosling, S. D., \& Potter, J. (2003). Development of personality in early and middle adulthood: Set like plaster or persistent change? Journal of Personality and Social Psychology, 84, 1041-1053.

Stout, J. G., Dasgupta, N., Hunsinger, M., McManus, M. A. (2011). STEMing the tide: using ingroup experts to inoculate women's self-concept in science, technology, engineering, and mathematics (STEM). Journal of personality and social psychology, 100(2), 255.

Tupes, E. C., Christal, R. E. (1961). Recurrent personality factors based on trait ratings (No. ASD-TR-61-97). PERSONNEL RESEARCH LAB LACKLAND AFB TX.

Udo, M. K., Ramsey, G. P., Reynolds-Alpert, S., Mallow, J. V. (2001). Does physics teaching affect gender-based science anxiety?. Journal of Science Education and Technology, $10(3), 237-247$.

Udo, M. K., Ramsey, G. P., Mallow, J. V. (2004). Science anxiety and gender in students taking general education science courses. Journal of Science Education and Technology, 13(4), 435-446.

Weisberg, Y. J., DeYoung, C. G., Hirsh, J. B. (2011). Gender differences in personality across the ten aspects of the Big Five.

Xu, Y. J. (2008). Gender disparity in STEM disciplines: A study of faculty attrition and turnover intentions. Research in Higher Education, 49(7), 607-624. 


\section{APPENDIX A: DESCRIPTIVE STATISTICS}

\section{SECTION 1: SAMPLES}

A1: Aggregated Physics Participants, Duplicates Students Averaged

\begin{tabular}{|c|c|c|c|}
\hline \multicolumn{4}{|c|}{ Physics Students } \\
\hline & Total & Female & Male \\
\hline Fall + Spring & 765 & 168 & 597 \\
\hline
\end{tabular}

A2: All Physics Participants, Disaggregated by Course, Duplicates Removed

\begin{tabular}{|c|c|c|c|}
\hline \multicolumn{5}{|c|}{ P111 } \\
\hline & Total & Female & Male \\
\hline Fall + Spring & 323 & 78 & 245 \\
\hline \multicolumn{3}{|c|}{ P112 } \\
\hline Fall + Spring & 277 & 52 & 225 \\
\hline
\end{tabular}

A3: All Physics Participants, Disaggregated by Semester and Course

\begin{tabular}{|c|c|c|c|}
\hline \multicolumn{5}{|c|}{ P111 } \\
\hline Spring & Total & Female & Male \\
\hline Fall & 296 & 72 & 224 \\
\hline \multicolumn{4}{|c|}{ P112 } \\
\hline Spring & 197 & 36 & 161 \\
\hline Fall & 192 & 44 & 148 \\
\hline
\end{tabular}

A4: All Math Participants, Disaggregated by Course

\begin{tabular}{|c|c|c|c|}
\hline \multicolumn{5}{|c|}{ M112-122 } \\
\hline & Total & Female & Male \\
\hline Fall & 387 & 255 & 132 \\
\hline \multicolumn{4}{|c|}{ M153-155 } \\
\hline Fall & 669 & 228 & 441 \\
\hline
\end{tabular}




\section{A5: COURSE DEMOGRAPHICS}

\begin{tabular}{|c|c|c|c|}
\hline \multicolumn{4}{|c|}{ Overall } \\
\hline Course & $\mathbf{N}$ & $\%$ Female & \% Male \\
\hline Spring P111 & 296 & 24 & 76 \\
\hline Spring P112 & 192 & 23 & 77 \\
\hline Fall P111 & 197 & 18 & 82 \\
\hline Fall P112 & 245 & 22 & 78 \\
\hline M112-122 & 387 & 66 & 34 \\
\hline M153-155 & 669 & 34 & 66 \\
\hline \multicolumn{4}{|c|}{ Spring 15 - P111 } \\
\hline Major & $\%$ & \% Female & \% Male \\
\hline Engineering & 90 & 22 & 68 \\
\hline Non-Science & 1 & 0 & 0 \\
\hline Other Science & 5 & 1 & 4 \\
\hline Physics & 3 & 0 & 3 \\
\hline Undecided/Other & 1 & 0 & 1 \\
\hline \multicolumn{4}{|c|}{ Spring $15-$ P112 } \\
\hline Engineering & 85 & 15 & 70 \\
\hline Non-Science & 1 & 1 & 1 \\
\hline Other Science & 11 & 3 & 8 \\
\hline Physics & 2 & 1 & 1 \\
\hline Undecided/Other & 1 & 0 & 1 \\
\hline \multicolumn{4}{|c|}{ Fall $15-$ P111 } \\
\hline Engineering & 84 & 16 & 68 \\
\hline Non-Science & 5 & 3 & 2 \\
\hline Other Science & 8 & 4 & 4 \\
\hline Physics & 2 & 0 & 2 \\
\hline Undecided/Other & 1 & 0 & 1 \\
\hline \multicolumn{4}{|c|}{ Fall 15-P112 } \\
\hline Engineering & 94 & 20 & 74 \\
\hline Non-Science & 1 & 1 & 0 \\
\hline Other Science & 2 & 0 & 2 \\
\hline Physics & 3 & 1 & 2 \\
\hline Undecided/Other & 0 & 0 & 0 \\
\hline \multicolumn{4}{|c|}{ M112-122 } \\
\hline Engineering & 5 & 0 & 5 \\
\hline Non-Science & 72 & 48 & 24 \\
\hline Other Science & 6 & 5 & 1 \\
\hline Physics & 0 & 0 & 0 \\
\hline Undecided/Other & 17 & 12 & 5 \\
\hline \multicolumn{4}{|c|}{ M153-155 } \\
\hline Engineering & 64 & 13 & 51 \\
\hline Non-Science & 16 & 12 & 4 \\
\hline Other Science & 17 & 9 & 8 \\
\hline Physics & 1 & 0 & 1 \\
\hline Undecided/Other & 2 & 1 & 1 \\
\hline
\end{tabular}




\section{SECTION 2: DESCRIPTIVE STATISTICS OF PERFORMANCE PREDICTORS}

A6: Sample A - All physics students

\begin{tabular}{|l|c|c|c|}
\hline Study Variables & Pooled (N=765) & Females (N=168) & Males(N=597) \\
\hline $\begin{array}{l}\text { ACT/SAT Math } \\
\text { Percentile }\end{array}$ & Mean(SD) & Mean(SD) & Mean(SD) \\
\hline $\begin{array}{l}\text { ACT/SAT Verbal } \\
\text { Percentile }\end{array}$ & $78(16)$ & $80(25)$ & $78(16)$ \\
\hline HSGPA & $70(21)$ & $74(21)$ & $68(21)$ \\
\hline Physics Grade & $3.8(.5)$ & $4.0(.4)$ & $3.7(.5)$ \\
\hline
\end{tabular}

A7: Sample B - Physics students, disaggregated by course

\begin{tabular}{|l|c|c|c|}
\hline \multicolumn{4}{|c|}{ P111 } \\
\hline Study Variables & Pooled (N=323) & Females (N=78) & Males (N=245) \\
\hline $\begin{array}{l}\text { ACT/SAT Math } \\
\text { Percentile }\end{array}$ & Mean(SD) & Mean(SD) & Mean(SD) \\
\hline $\begin{array}{l}\text { ACT/SAT Verbal } \\
\text { Percentile }\end{array}$ & $78(16)$ & $79(16)$ & $77(15)$ \\
\hline High School GPA & $69(22)$ & $76(19)$ & $67(22)$ \\
\hline Physics Grade & $3.7(.5)$ & $4.0(.4)$ & $3.6(.5)$ \\
\hline & $2.8(1)$ & $2.9(1.5)$ & $2.7(1)$ \\
\hline & \multicolumn{1}{|c|}{ P112 } & Males (N=225) \\
\hline & Pooled (N=277) & Females (N=52) & Mean(SD) \\
\hline $\begin{array}{l}\text { ACT/SAT Math } \\
\text { Percentile }\end{array}$ & Mean(SD) & Mean(SD) & $77(17)$ \\
\hline $\begin{array}{l}\text { ACT/SAT Verbal } \\
\text { Percentile }\end{array}$ & $77(16)$ & $80(15)$ & $66(22)$ \\
\hline HSGPA & $67(22)$ & $69(24)$ & $3.7(.5)$ \\
\hline Physics Grade & $3.7(.5)$ & $3.9(.4)$ & $2.8(.9)$ \\
\hline
\end{tabular}


A8: Sample C Physics students, disaggregated by semester and course

\begin{tabular}{|c|c|c|c|}
\hline \multicolumn{4}{|c|}{ Spring } \\
\hline \multicolumn{4}{|c|}{ P111 } \\
\hline Study Variables & Pooled $(\mathrm{N}=296)$ & Females $(\mathrm{N}=72)$ & Males $(\mathrm{N}=224)$ \\
\hline & Mean(SD) & Mean(SD) & Mean(SD) \\
\hline ACTSAT Math Percentile & $83(14)$ & $83(12)$ & $82(14)$ \\
\hline ACTSAT Verbal Percentile & $75(19)$ & $78(19)$ & $74(19)$ \\
\hline HSGPA & $3.8(.4)$ & $4.0(.4)$ & $3.8(.4)$ \\
\hline Physics Grade & $3.1(.9)$ & $3.2(.9)$ & $3.1(.9)$ \\
\hline \multicolumn{4}{|c|}{ P112 } \\
\hline & Pooled (N=197) & Females $(\mathrm{N}=36)$ & Males $(\mathrm{N}=161)$ \\
\hline ACTSAT Math Percentile & $76(16)$ & $78(16)$ & $75(16)$ \\
\hline ACTSAT Verbal Percentile & $65(22)$ & $67(25)$ & $64(21)$ \\
\hline HSGPA & $3.7(0.5)$ & $3.9(.4)$ & $3.6(.5)$ \\
\hline Physics Grade & $2.9(.9)$ & $3.1(.9)$ & $2.8(.9)$ \\
\hline \multicolumn{4}{|c|}{ Fall } \\
\hline \multicolumn{4}{|c|}{ P111 } \\
\hline Study Variables & Pooled (N=192) & Females $(\mathrm{N}=44)$ & Males $(\mathrm{N}=148)$ \\
\hline & Mean(SD) & Mean(SD) & Mean(SD) \\
\hline ACTSAT Math Percentile & $75(16)$ & $76(18)$ & $75(15)$ \\
\hline ACTSAT Verbal Percentile & $66(22)$ & $75(20)$ & $63(22)$ \\
\hline HSGPA & $3.7(.5)$ & $4.0(.4)$ & $3.6(.5)$ \\
\hline Physics Grade & $2.7(1.1)$ & $2.7(1.2)$ & $2.6(1)$ \\
\hline \multicolumn{4}{|c|}{ P112 } \\
\hline & Pooled $(\mathrm{N}=\mathbf{2 4 5})$ & Females $(\mathrm{N}=54)$ & Males $(\mathrm{N}=191)$ \\
\hline ACTSAT Math Percentile & $83(14)$ & $83(12)$ & $82(14)$ \\
\hline ACTSAT Verbal Percentile & $75(19)$ & $77(20)$ & 74(19) \\
\hline HSGPA & $3.9(.4)$ & $3.9(.4)$ & $3.9(.4)$ \\
\hline Physics Grade & $3.0(.9)$ & $3.2(.9)$ & $3.0(.9)$ \\
\hline
\end{tabular}

A9: Sample D Mathematics students, disaggregated by course

\begin{tabular}{|l|c|c|c|}
\hline \multicolumn{5}{|c|}{ M112-122 } \\
\hline & Pooled (N=387) & Females (N=255) & Males (N=132) \\
\hline ACTSAT Math Percentile & $37(13)$ & $36(12)$ & $38(14)$ \\
\hline HSGPA & $3.2(.4)$ & $3.3(.4)$ & $3.0(.4)$ \\
\hline \multicolumn{4}{|c|}{ M153-155 } \\
\hline & Pooled (N=669) & Females (N=228) & Males (N=441) \\
\hline ACTSAT Math Percentile & $85(14)$ & $82(15)$ & $86(14)$ \\
\hline HSGPA & $3.8(.4)$ & $3.9(.4)$ & $3.8(.4)$ \\
\hline
\end{tabular}


SECTION 3: BFI RESULTS

A10: BFI Means

\begin{tabular}{|c|c|c|c|c|c|c|c|c|c|}
\hline & \multicolumn{3}{|c|}{ Sample A } & \multicolumn{3}{|c|}{ M112-122 } & \multicolumn{2}{|c|}{$\begin{array}{c}\text { Srivastava } \\
2003\end{array}$} & \multirow{2}{*}{$\begin{array}{c}\text { Peterson } \\
2006\end{array}$} \\
\hline & Total & $\mathbf{F}$ & $\mathbf{M}$ & Total & $\mathbf{F}$ & M & $\mathbf{F}$ & $\mathbf{M}$ & \\
\hline Openness & $3.7(.5)$ & $3.7(.6)$ & $3.7(.5)$ & $3.4(.6)$ & $3.4(.6)$ & $3.5(.5)$ & 3.9 & 4.1 & 3.68 \\
\hline Conscientiousness & $3.7(.6)$ & $3.8(.6)$ & $3.6(.6)$ & $3.6(.6)$ & $3.7(.7)$ & $3.5(.6)$ & 3.5 & 3.3 & 3.92 \\
\hline Extraversion & $3.3(.8)$ & $3.4(.9)$ & $3.2(.7)$ & $3.4(.7)$ & $3.4(.7)$ & $3.4(.7)$ & 3.3 & 3.1 & 3.50 \\
\hline Agreeableness & $3.8(.6)$ & $3.9(.6)$ & $3.8(.6)$ & $3.9(.6)$ & $4.0(.6)$ & $3.8(.6)$ & 3.6 & 3.6 & 4.10 \\
\hline Neuroticism & $2.8(.7)$ & $3.0(.7)$ & $2.7(.7)$ & $3.1(.7)$ & $3.3(.7)$ & $2.8(.8)$ & 3.3 & 2.8 & 2.81 \\
\hline
\end{tabular}

A11: Sample B BFI Means

\begin{tabular}{|l|c|c|c|c|c|c|}
\hline \multirow{2}{*}{ Openness } & \multicolumn{3}{|c|}{ P111 } & \multicolumn{3}{c|}{ P112 } \\
\cline { 2 - 6 } & Total & F & M & Total & F & M \\
\hline Conscientiousness & $3.7(.5)$ & $3.8(.6)$ & $3.6(.5)$ & $3.7(.5)$ & $3.7(.5)$ & $3.7(.5)$ \\
\hline Extraversion & $3.6(.6)$ & $3.8(.7)$ & $3.5(.5)$ & $3.7(.6)$ & $3.8(.7)$ & $3.7(.6)$ \\
\hline Agreeableness & $3.2(.8)$ & $3.3(.9)$ & $3.2(.7)$ & $3.3(.8)$ & $3.6(.8)$ & $3.2(.8)$ \\
\hline Neuroticism & $3.8(.6)$ & $3.9(.6)$ & $3.7(.6)$ & $3.8(.6)$ & $3.9(.6)$ & $3.8(.6)$ \\
\hline
\end{tabular}

A12: Sample C BFI Means

\begin{tabular}{|c|c|c|c|c|c|c|}
\hline \multicolumn{7}{|c|}{ Spring } \\
\hline & \multicolumn{3}{|c|}{ P111 } & \multicolumn{3}{|c|}{ P112 } \\
\hline & Total & $\mathbf{F}$ & $\mathbf{M}$ & Total & $\mathbf{F}$ & $\mathbf{M}$ \\
\hline Openness & $3.7(.5)$ & $3.7(.6)$ & $3.7(.5)$ & $3.7(.5)$ & $3.7(.5)$ & $3.17 .5)$ \\
\hline Conscientiousness & $3.7(.6)$ & $3.7(.7)$ & $3.6(.6)$ & $3.7(.6)$ & $3.8(.6)$ & $3.7(.6)$ \\
\hline Extraversion & $3.2(.8)$ & $3.2(.9)$ & $3.2(.8)$ & $3.3(.8)$ & $3.6(.8)$ & $3.3(.6)$ \\
\hline Agreeableness & $3.8(.6)$ & $3.9(.6)$ & $3.8(.6)$ & $3.8(.6)$ & $4.0(.6)$ & $3.8(.6)$ \\
\hline Neuroticism & $2.8(.7)$ & $3.1(.7)$ & $2.7(.7)$ & $2.7(.7)$ & $2.9(.7)$ & $2.6(.7)$ \\
\hline \multicolumn{7}{|c|}{ Fall } \\
\hline & \multicolumn{3}{|c|}{ P111 } & \multicolumn{3}{|c|}{ P112 } \\
\hline & Total & $\mathbf{F}$ & $\mathbf{M}$ & Total & $\mathbf{F}$ & $\mathbf{M}$ \\
\hline Openness & $3.6(.5)$ & $3.8(.6)$ & $3.6(.5)$ & $3.6(.5)$ & $3.6(.6)$ & $3.6(.5)$ \\
\hline Conscientiousness & $3.6(.6)$ & $3.9(.6)$ & $3.6(.5)$ & $3.7(.6)$ & $3.8(.6)$ & $3.7(.6)$ \\
\hline Extraversion & $3.2(.8)$ & $3.3(.9)$ & $3.2(.7)$ & $3.2(.8)$ & $3.4(.8)$ & $3.2(.8)$ \\
\hline Agreeableness & $3.8(.6)$ & $3.9(.6)$ & $3.7(.6)$ & $3.8(.6)$ & $3.9(.6)$ & $3.8(.6)$ \\
\hline Neuroticism & $2.8(.7)$ & $3.3(.7)$ & $2.7(.7)$ & $2.8(.8)$ & $3.2(.7)$ & $2.7(.8)$ \\
\hline
\end{tabular}


A13: Sample D BFI Means

\begin{tabular}{|l|c|c|c|c|c|c|}
\hline \multirow{2}{*}{ Openness } & \multicolumn{3}{|c|}{ M112-122 } & \multicolumn{3}{c|}{ M153-155 } \\
\cline { 2 - 7 } & Total & F & M & Total & F & M \\
\hline Conscientiousness & $3.4(.6)$ & $3.4(.6)$ & $3.5(.5)$ & $3.5(.6)$ & $3.5(.6)$ & $3.6(.5)$ \\
\hline Extraversion & $3.6(.6)$ & $3.7(.7)$ & $3.5(.6)$ & $3.6(.6)$ & $3.7(.5)$ & $3.5(.6)$ \\
\hline Agreeableness & $3.4(.7)$ & $3.4(.7)$ & $3.4(.7)$ & $3.2(.8)$ & $3.1(.9)$ & $3.2(.7)$ \\
\hline Neuroticism & $3.9(.6)$ & $4.0(.6)$ & $3.8(.6)$ & $3.8(.6)$ & $3.8(.7)$ & $3.7(.5)$ \\
\hline
\end{tabular}




\section{APPENDIX B: STATISTICAL ANALYSIS RESULTS}

ANOVA results of comparisons between BFI means. Statistical significance denoted by superscripts - "a" $p<0.05$, "b" $p<0.01$, "c" $p<0.001$.

\section{SECTION 1: ANOVA RESULTS}

B1 - Comparing BFI Results between Aggregated Physics Courses and M112-122

\begin{tabular}{|c|c|c|c|c|c|c|}
\hline & & Sum of Squares & df & Mean Square & $\mathbf{F}$ & Sig. \\
\hline \multirow{3}{*}{ Openness } & Between Groups & 13.5 & 1 & 13.53 & 47.02 & $0.00^{\mathrm{c}}$ \\
\hline & Within Groups & 523.3 & 1819 & 0.29 & & \\
\hline & Total & 536.8 & 1820 & & & \\
\hline \multirow{3}{*}{ Conscientiousness } & Between Groups & 0.7 & 1 & 0.73 & 2.16 & 0.14 \\
\hline & Within Groups & 611.4 & 1819 & 0.34 & & \\
\hline & Total & 612.1 & 1820 & & & \\
\hline \multirow{3}{*}{ Extraversion } & Between Groups & 0.02 & 1 & 0.02 & 0.03 & 0.87 \\
\hline & Within Groups & 1087.2 & 1819 & 0.6 & & \\
\hline & Total & 1087.3 & 1820 & & & \\
\hline \multirow{3}{*}{ Agreeableness } & Between Groups & 0.1 & 1 & 0.1 & 0.28 & 0.6 \\
\hline & Within Groups & 669.8 & 1819 & 0.37 & & \\
\hline & Total & 669.9 & 1820 & & & \\
\hline \multirow{3}{*}{ Neuroticism } & Between Groups & 27.7 & 1 & 27.66 & 50.33 & $0.00^{\mathrm{c}}$ \\
\hline & Within Groups & 999.6 & 1819 & 0.55 & & \\
\hline & Total & 1027.2 & 1820 & & & \\
\hline
\end{tabular}

B2 - Comparing BFI Results between Female and Male Students from Sample A

\begin{tabular}{|l|l|c|c|c|c|c|}
\hline & & Sum of Squares & df & Mean Square & F & Sig. \\
\hline \multirow{4}{*}{ Openness } & Between Groups & 0.3 & 1 & 0.31 & 1.21 & 0.27 \\
\hline & Within Groups & 196.0 & 763 & 0.26 & & \\
\cline { 2 - 7 } & Total & 196.3 & 764 & & & \\
\hline \multirow{4}{*}{ Conscientiousness } & Between Groups & 3.4 & 1 & 3.44 & 10.23 & $0.00^{\mathrm{c}}$ \\
\cline { 2 - 7 } & Within Groups & 256.8 & 763 & 0.34 & & \\
\hline & Total & 260.2 & 764 & & & \\
\hline \multirow{4}{*}{ Agreeableness } & Between Groups & 2.7 & 1 & 2.68 & 4.57 & $0.03^{\mathrm{a}}$ \\
\hline & Within Groups & 447.4 & 763 & 0.59 & & \\
\hline & Total & 450.2 & 764 & & & \\
\hline \multirow{3}{*}{ Neuroticism } & Between Groups & 2.9 & 1 & 2.85 & 8.59 & $0.00^{\mathrm{b}}$ \\
\hline & Within Groups & 253.1 & 763 & 0.33 & & \\
\hline & Total & 255.9 & 764 & & & \\
\hline & Between Groups & 23.9 & 1 & 23.93 & 48.87 & $0.00^{\mathrm{c}}$ \\
\hline & Within Groups & 373.6 & 763 & 0.49 & & \\
\hline & Total & 397.5 & 764 & & & \\
\hline
\end{tabular}


B3 - Aggregated P111, Comparing BFI Results between Female and Male Students

\begin{tabular}{|c|c|c|c|c|c|c|}
\hline & & $\begin{array}{c}\text { Sum of } \\
\text { Squares }\end{array}$ & df & Mean Square & $\mathbf{F}$ & Sig. \\
\hline \multirow{3}{*}{ Openness } & Between Groups & 1.09 & 1.00 & 1.09 & 3.93 & $0.05^{\mathrm{a}}$ \\
\hline & Within Groups & 89.01 & 321.00 & 0.28 & & \\
\hline & Total & 90.10 & 322.00 & & & \\
\hline \multirow{3}{*}{ Conscientiousness } & Between Groups & 5.04 & 1.00 & 5.04 & 15.72 & $0.00^{\mathrm{c}}$ \\
\hline & Within Groups & 102.95 & 321.00 & 0.32 & & \\
\hline & Total & 107.99 & 322.00 & & & \\
\hline \multirow{3}{*}{ Extraversion } & Between Groups & 0.21 & 1.00 & 0.21 & 0.36 & 0.55 \\
\hline & Within Groups & 191.78 & 321.00 & 0.60 & & \\
\hline & Total & 191.99 & 322.00 & & & \\
\hline \multirow{3}{*}{ Agreeableness } & Between Groups & 1.91 & 1.00 & 1.91 & 5.85 & $0.02^{\mathrm{a}}$ \\
\hline & Within Groups & 104.66 & 321.00 & 0.33 & & \\
\hline & Total & 106.56 & 322.00 & & & \\
\hline \multirow{3}{*}{ Neuroticism } & Between Groups & 11.18 & 1.00 & 11.18 & 23.86 & $0.00^{\mathrm{c}}$ \\
\hline & Within Groups & 150.39 & 321.00 & 0.47 & & \\
\hline & Total & 161.57 & 322.00 & & & \\
\hline
\end{tabular}

B4 - Aggregated P112, Comparing BFI Results between Female and Male Students

\begin{tabular}{|c|c|c|c|c|c|c|}
\hline & & $\begin{array}{l}\text { Sum of } \\
\text { Squares }\end{array}$ & df & Mean Square & $\mathbf{F}$ & Sig. \\
\hline \multirow{3}{*}{ Openness } & Between Groups & 0.13 & 1.00 & 0.13 & 0.53 & 0.47 \\
\hline & Within Groups & 65.53 & 275.00 & 0.24 & & \\
\hline & Total & 65.65 & 276.00 & & & \\
\hline \multirow{3}{*}{ Conscientiousness } & Between Groups & 0.46 & 1.00 & 0.46 & 1.27 & 0.26 \\
\hline & Within Groups & 99.33 & 275.00 & 0.36 & & \\
\hline & Total & 99.79 & 276.00 & & & \\
\hline \multirow{3}{*}{ Extraversion } & Between Groups & 5.89 & 1.00 & 5.89 & 10.10 & $0.00^{\circ}$ \\
\hline & Within Groups & 160.35 & 275.00 & 0.58 & & \\
\hline & Total & 166.24 & 276.00 & & & \\
\hline \multirow{3}{*}{ Agreeableness } & Between Groups & 1.14 & 1.00 & 1.14 & 2.99 & 0.09 \\
\hline & Within Groups & 104.21 & 275.00 & 0.38 & & \\
\hline & Total & 105.34 & 276.00 & & & \\
\hline \multirow{3}{*}{ Neuroticism } & Between Groups & 4.86 & 1.00 & 4.86 & 9.11 & $0.00^{\circ}$ \\
\hline & Within Groups & 146.84 & 275.00 & 0.53 & & \\
\hline & Total & 151.70 & 276.00 & & & \\
\hline
\end{tabular}


B5 - Spring 15 P111, Comparing BFI Results between Female and Male Students

\begin{tabular}{|c|c|c|c|c|c|c|}
\hline & & $\begin{array}{l}\text { Sum of } \\
\text { Squares }\end{array}$ & df & Mean Square & $\mathbf{F}$ & Sig. \\
\hline \multirow{3}{*}{ Openness } & Between Groups & 0.00 & 1.00 & 0.00 & 0.00 & 0.99 \\
\hline & Within Groups & 83.63 & 294.00 & 0.28 & & \\
\hline & Total & 83.63 & 295.00 & & & \\
\hline \multirow{3}{*}{ Conscientiousness } & Between Groups & 0.54 & 1.00 & 0.54 & 1.45 & 0.23 \\
\hline & Within Groups & 109.30 & 294.00 & 0.37 & & \\
\hline & Total & 109.84 & 295.00 & & & \\
\hline \multirow{3}{*}{ Extraversion } & Between Groups & 0.02 & 1.00 & 0.02 & 0.04 & 0.85 \\
\hline & Within Groups & 180.99 & 294.00 & 0.62 & & \\
\hline & Total & 181.02 & 295.00 & & & \\
\hline \multirow{3}{*}{ Agreeableness } & Between Groups & 0.41 & 1.00 & 0.41 & 1.31 & 0.25 \\
\hline & Within Groups & 92.20 & 294.00 & 0.31 & & \\
\hline & Total & 92.61 & 295.00 & & & \\
\hline \multirow{3}{*}{ Neuroticism } & Between Groups & 8.38 & 1.00 & 8.38 & 17.77 & $0.00^{\circ}$ \\
\hline & Within Groups & 138.57 & 294.00 & 0.47 & & \\
\hline & Total & 146.95 & 295.00 & & & \\
\hline
\end{tabular}

B6 - Spring 15 P112, Comparing BFI Results between Female and Male Students

\begin{tabular}{|c|c|c|c|c|c|c|}
\hline & & $\begin{array}{l}\text { Sum of } \\
\text { Squares }\end{array}$ & df & Mean Square & $\mathbf{F}$ & Sig. \\
\hline \multirow{3}{*}{ Openness } & Between Groups & 0.08 & 1.00 & 0.08 & 0.36 & 0.55 \\
\hline & Within Groups & 45.82 & 195.00 & 0.24 & & \\
\hline & Total & 45.91 & 196.00 & & & \\
\hline \multirow{3}{*}{ Conscientiousness } & Between Groups & 0.48 & 1.00 & 0.48 & 1.32 & 0.25 \\
\hline & Within Groups & 70.63 & 195.00 & 0.36 & & \\
\hline & Total & 71.11 & 196.00 & & & \\
\hline \multirow{3}{*}{ Extraversion } & Between Groups & 2.59 & 1.00 & 2.59 & 4.51 & $0.04^{\mathrm{a}}$ \\
\hline & Within Groups & 112.15 & 195.00 & 0.58 & & \\
\hline & Total & 114.74 & 196.00 & & & \\
\hline \multirow{3}{*}{ Agreeableness } & Between Groups & 1.26 & 1.00 & 1.26 & 3.28 & 0.07 \\
\hline & Within Groups & 74.90 & 195.00 & 0.38 & & \\
\hline & Total & 76.16 & 196.00 & & & \\
\hline \multirow{3}{*}{ Neuroticism } & Between Groups & 2.65 & 1.00 & 2.65 & 5.41 & $0.02^{\mathrm{a}}$ \\
\hline & Within Groups & 95.40 & 195.00 & 0.49 & & \\
\hline & Total & 98.05 & 196.00 & & & \\
\hline
\end{tabular}


B7 - Fall 15 P111, Comparing BFI Results between Female and Male Students

\begin{tabular}{|c|c|c|c|c|c|c|}
\hline & & $\begin{array}{l}\text { Sum of } \\
\text { Squares }\end{array}$ & df & Mean Square & $\mathbf{F}$ & Sig. \\
\hline \multirow{3}{*}{ Openness } & Between Groups & 2.06 & 1.00 & 2.06 & 7.78 & $0.01^{\mathrm{a}}$ \\
\hline & Within Groups & 50.19 & 190.00 & 0.26 & & \\
\hline & Total & 52.25 & 191.00 & & & \\
\hline \multirow{3}{*}{ Conscientiousness } & Between Groups & 2.98 & 1.00 & 2.98 & 10.47 & $0.00^{\mathrm{c}}$ \\
\hline & Within Groups & 54.02 & 190.00 & 0.28 & & \\
\hline & Total & 56.99 & 191.00 & & & \\
\hline \multirow{3}{*}{ Extraversion } & Between Groups & 0.44 & 1.00 & 0.44 & 0.77 & 0.38 \\
\hline & Within Groups & 107.78 & 190.00 & 0.57 & & \\
\hline & Total & 108.21 & 191.00 & & & \\
\hline \multirow{3}{*}{ Agreeableness } & Between Groups & 1.09 & 1.00 & 1.09 & 3.25 & 0.07 \\
\hline & Within Groups & 63.48 & 190.00 & 0.33 & & \\
\hline & Total & 64.57 & 191.00 & & & \\
\hline \multirow{3}{*}{ Neuroticism } & Between Groups & 10.50 & 1.00 & 10.50 & 22.30 & $0.00^{\mathrm{c}}$ \\
\hline & Within Groups & 89.50 & 190.00 & 0.47 & & \\
\hline & Total & 100.00 & 191.00 & & & \\
\hline
\end{tabular}

B8 - Fall 15 P112, Comparing BFI Results between Female and Male Students

\begin{tabular}{|c|c|c|c|c|c|c|}
\hline & & $\begin{array}{c}\text { Sum of } \\
\text { Squares }\end{array}$ & df & Mean Square & $\mathbf{F}$ & Sig. \\
\hline \multirow{3}{*}{ Openness } & Between Groups & 0.01 & 1.00 & 0.01 & 0.04 & 0.84 \\
\hline & Within Groups & 66.02 & 243.00 & 0.27 & & \\
\hline & Total & 66.03 & 244.00 & & & \\
\hline \multirow{3}{*}{ Conscientiousness } & Between Groups & 0.15 & 1.00 & 0.15 & 0.43 & 0.51 \\
\hline & Within Groups & 86.13 & 243.00 & 0.35 & & \\
\hline & Total & 86.29 & 244.00 & & & \\
\hline \multirow{3}{*}{ Extraversion } & Between Groups & 1.65 & 1.00 & 1.65 & 2.77 & 0.10 \\
\hline & Within Groups & 144.17 & 243.00 & 0.59 & & \\
\hline & Total & 145.82 & 244.00 & & & \\
\hline \multirow{3}{*}{ Agreeableness } & Between Groups & 0.41 & 1.00 & 0.41 & 1.24 & 0.27 \\
\hline & Within Groups & 79.90 & 243.00 & 0.33 & & \\
\hline & Total & 80.31 & 244.00 & & & \\
\hline \multirow{3}{*}{ Neuroticism } & Between Groups & 10.45 & 1.00 & 10.45 & 18.17 & $0.00^{\mathrm{c}}$ \\
\hline & Within Groups & 139.78 & 243.00 & 0.58 & & \\
\hline & Total & 150.23 & 244.00 & & & \\
\hline
\end{tabular}


B9 - Fall 15 M112-122, Comparing BFI Results between Female and Male Students

\begin{tabular}{|c|c|c|c|c|c|c|}
\hline & & $\begin{array}{c}\text { Sum of } \\
\text { Squares }\end{array}$ & df & Mean Square & $\mathbf{F}$ & Sig. \\
\hline \multirow{3}{*}{ Openness } & Between Groups & 0.43 & 1 & 0.43 & 1.42 & 0.24 \\
\hline & Within Groups & 116.26 & 385 & 0.30 & & \\
\hline & Total & 116.69 & 386 & & & \\
\hline \multirow{3}{*}{ Conscientiousness } & Between Groups & 2.11 & 1 & 2.11 & 6.38 & $0.01^{\mathrm{a}}$ \\
\hline & Within Groups & 127.31 & 385 & 0.33 & & \\
\hline & Total & 129.42 & 386 & & & \\
\hline \multirow{3}{*}{ Extraversion } & Between Groups & 0.01 & 1 & 0.01 & 0.01 & 0.91 \\
\hline & Within Groups & 207.39 & 385 & 0.54 & & \\
\hline & Total & 207.40 & 386 & & & \\
\hline \multirow{3}{*}{ Agreeableness } & Between Groups & 5.01 & 1 & 5.01 & 13.54 & $0.00^{\mathrm{c}}$ \\
\hline & Within Groups & 142.53 & 385 & 0.37 & & \\
\hline & Total & 147.54 & 386 & & & \\
\hline \multirow{3}{*}{ Neuroticism } & Between Groups & 17.72 & 1 & 17.72 & 36.65 & $0.00^{\mathrm{c}}$ \\
\hline & Within Groups & 186.11 & 385 & 0.48 & & \\
\hline & Total & 203.83 & 386 & & & \\
\hline
\end{tabular}

B10 - Fall 15 M153-155, Comparing BFI Results between Female and Male Students

\begin{tabular}{|c|c|c|c|c|c|c|}
\hline & & $\begin{array}{c}\text { Sum of } \\
\text { Squares }\end{array}$ & df & Mean Square & $\mathbf{F}$ & Sig. \\
\hline \multirow{3}{*}{ Openness } & Between Groups & 0.11 & 1 & 0.11 & 0.35 & 0.56 \\
\hline & Within Groups & 205.87 & 667 & 0.31 & & \\
\hline & Total & 205.98 & 668 & & & \\
\hline \multirow{3}{*}{ Conscientiousness } & Between Groups & 5.58 & 1 & 5.58 & 17.23 & $0.00^{\mathrm{c}}$ \\
\hline & Within Groups & 215.92 & 667 & 0.32 & & \\
\hline & Total & 221.50 & 668 & & & \\
\hline \multirow{3}{*}{ Extraversion } & Between Groups & 1.11 & 1 & 1.11 & 1.77 & 0.18 \\
\hline & Within Groups & 415.67 & 667 & 0.62 & & \\
\hline & Total & 416.78 & 668 & & & \\
\hline \multirow{3}{*}{ Agreeableness } & Between Groups & 1.90 & 1 & 1.90 & 4.91 & $0.03^{\mathrm{a}}$ \\
\hline & Within Groups & 257.76 & 667 & 0.39 & & \\
\hline & Total & 259.66 & 668 & & & \\
\hline \multirow{3}{*}{ Neuroticism } & Between Groups & 49.28 & 1 & 49.28 & 95.62 & $0.00^{\mathrm{c}}$ \\
\hline & Within Groups & 343.77 & 667 & 0.52 & & \\
\hline & Total & 393.05 & 668 & & & \\
\hline
\end{tabular}




\section{SECTION 2: HIERARCHAL LINEAR REGRESSION RESULTS}

The following set of tables contain the results of the Hierarchal Linear Regression Models. Statistical significance denoted by superscripts - "a" $p<0.05$, "b" $p<0.01$, "c" $p<0.001$. There are seven models used in this study:

Model $1-$ ACT/SAT Math Percentile + ACT/SAT Verbal Percentile $\Rightarrow$ Physics Grade

Model 2 - Openness + Conscientiousness + Extraversion + Agreeableness + Neuroticism $\Rightarrow$ Physics Grade

Model 3 - High School GPA $\Rightarrow$ Physics Grade

Model 4 - ACT/SAT Math Percentile + ACT/SAT Verbal Percentile + High School GPA $\Rightarrow$ Physics Grade

Model 5 - ACT/SAT Math Percentile + ACT/SAT Verbal Percentile + Openness + Conscientiousness + Extraversion + Agreeableness + Neuroticism $\Rightarrow$ Physics Grade

Model 6 - High School GPA + Openness + Conscientiousness + Extraversion + Agreeableness + Neuroticism $\Rightarrow$ Physics Grade

Model 7 - ACT/SAT Math Percentile + ACT/SAT Verbal Percentile + High School GPA + Openness + Conscientiousness + Extraversion + Agreeableness + Neuroticism $\Rightarrow$ Physics Grade 
B11 - Sample A, Aggregated Physics Students

\begin{tabular}{|c|c|c|c|c|c|c|c|c|c|c|c|c|}
\hline \multirow[t]{2}{*}{ Models } & \multicolumn{4}{|c|}{ Physics Students } & \multicolumn{4}{|c|}{ Female Physics Students } & \multicolumn{4}{|c|}{ Male Physics Students } \\
\hline & $\mathbf{R}^{2}$ & B & SE & $\beta$ & $\mathbf{R}^{2}$ & B & SE & $\beta$ & $\mathbf{R}^{2}$ & B & SE & $\beta$ \\
\hline M1 & 0.16 & & & & 0.22 & & & & 0.14 & & & \\
\hline ACTSATMath & & 0.02 & 0.00 & $.25^{\mathrm{c}}$ & & 0.02 & 0.01 & $0.28^{\mathrm{b}}$ & & 0.02 & 0.00 & $0.24^{\mathrm{c}}$ \\
\hline ACTSATVerb & & 0.01 & 0.00 & $.18^{\mathrm{c}}$ & & 0.01 & 0.01 & $0.23^{\mathrm{a}}$ & & 0.01 & 0.00 & $0.16^{\mathrm{c}}$ \\
\hline M2 & 0.05 & & & & 0.03 & & & & 0.06 & & & \\
\hline Openness & & 0.07 & 0.07 & 0.03 & & 0.05 & 0.14 & 0.03 & & 0.07 & 0.08 & 0.04 \\
\hline Conscientiousness & & 0.38 & 0.07 & $0.23^{\mathrm{c}}$ & & 0.21 & 0.13 & 0.14 & & 0.41 & 0.08 & $0.24^{\mathrm{c}}$ \\
\hline Extraversion & & -0.11 & 0.05 & -0.08 & & 0.02 & 0.1 & 0.02 & & -0.15 & 0.06 & $-0.12^{\mathrm{b}}$ \\
\hline Agreeableness & & -0.12 & 0.07 & -0.07 & & -0.16 & 0.15 & -0.09 & & -0.13 & 0.07 & -0.08 \\
\hline Neuroticism & & -0.02 & 0.05 & -0.02 & & 0.13 & 0.12 & 0.09 & & -0.1 & 0.06 & -0.07 \\
\hline M3 & 0.16 & & & & 0.31 & & & & 0.13 & & & \\
\hline HSGPA & & 0.82 & 0.07 & $0.40^{\mathrm{c}}$ & & 1.41 & 0.17 & $0.55^{\mathrm{c}}$ & & 0.73 & 0.08 & $0.36^{\mathrm{c}}$ \\
\hline M4 & 0.21 & & & & 0.37 & & & & 0.18 & & & \\
\hline HSGPA & & 0.52 & 0.08 & $0.27^{\mathrm{c}}$ & & 1.09 & 0.18 & $0.43^{\mathrm{c}}$ & & 0.48 & 0.09 & $0.23^{\mathrm{c}}$ \\
\hline ACTSATMath & & 0.01 & 0.00 & $0.18^{\mathrm{c}}$ & & 0.01 & 0.01 & $0.18^{\mathrm{a}}$ & & 0.01 & 0.00 & $0.17^{\mathrm{c}}$ \\
\hline ACTSATVerb & & 0.01 & 0.00 & 0.11 & & 0.01 & 0.00 & 0.13 & & 0.01 & 0.00 & $0.10^{\mathrm{a}}$ \\
\hline M5 & 0.20 & & & & 0.24 & & & & 0.19 & & & \\
\hline ACTSATMath & & 0.02 & 0.00 & $0.26^{\mathrm{c}}$ & & 0.02 & 0.01 & $0.29^{\mathrm{b}}$ & & 0.02 & 0.00 & $0.25^{\mathrm{c}}$ \\
\hline ACTSATVerb & & 0.01 & 0.00 & $0.17^{\mathrm{c}}$ & & 0.01 & 0.01 & 0.21 & & 0.01 & 0.00 & $0.15^{\mathrm{b}}$ \\
\hline Openness & & 0.001 & 0.07 & 0.00 & & -0.02 & 0.13 & -0.01 & & 0.01 & 0.08 & 0.00 \\
\hline Conscientiousness & & 0.36 & 0.06 & $0.22^{\mathrm{c}}$ & & 0.15 & 0.12 & 0.1 & & 0.41 & 0.07 & $0.25^{\mathrm{c}}$ \\
\hline Extraversion & & -0.07 & 0.04 & -0.05 & & 0.04 & 0.09 & 0.03 & & -0.1 & 0.05 & -0.08 \\
\hline Agreeableness & & -0.04 & 0.06 & -0.03 & & -0.04 & 0.14 & -0.03 & & -0.05 & 0.07 & -0.03 \\
\hline Neuroticism & & -0.01 & 0.05 & 0.00 & & 0.11 & 0.11 & 0.08 & & -0.05 & 0.06 & -0.03 \\
\hline M6 & 0.18 & & & & 0.31 & & & & 0.17 & & & \\
\hline HSGPA & & 0.78 & 0.07 & $0.38^{\mathrm{c}}$ & & 1.42 & 0.18 & $0.56^{\mathrm{c}}$ & & 0.68 & 0.08 & $0.34^{\mathrm{c}}$ \\
\hline Openness & & 0.08 & 0.07 & 0.04 & & 0.05 & 0.12 & 0.03 & & 0.08 & 0.08 & 0.04 \\
\hline Conscientiousness & & 0.26 & 0.06 & $0.16^{\mathrm{c}}$ & & -0.04 & 0.11 & -0.03 & & 0.33 & 0.07 & $0.19^{\mathrm{c}}$ \\
\hline Extraversion & & -0.09 & 0.05 & -0.07 & & 0.05 & 0.08 & 0.04 & & -0.13 & 0.05 & $-0.10^{b}$ \\
\hline Agreeableness & & -0.13 & 0.06 & -0.08 & & 0 & 0.13 & 0 & & -0.13 & 0.07 & $-0.08^{\mathrm{a}}$ \\
\hline Neuroticism & & -0.08 & 0.05 & -0.06 & & 0.08 & 0.1 & 0.06 & & -0.11 & 0.06 & $-0.08^{\mathrm{a}}$ \\
\hline M7 & 0.24 & & & & 0.38 & & & & 0.22 & & & \\
\hline HSGPA & & 0.50 & 0.08 & $0.24^{\mathrm{c}}$ & & 1.10 & 0.19 & $0.43^{\mathrm{c}}$ & & 0.41 & 0.09 & $0.20^{\mathrm{c}}$ \\
\hline ACTSATMath & & 0.01 & 0.003 & $0.19^{c}$ & & 0.01 & 0.01 & $0.19^{\mathrm{a}}$ & & 0.01 & 0.00 & $0.19^{\mathrm{c}}$ \\
\hline ACTSATVerb & & 0.005 & 0.002 & 0.11 & & 0.01 & 0.01 & 0.11 & & 0.01 & 0.00 & $0.10^{\mathrm{a}}$ \\
\hline Openness & & 0.03 & 0.06 & 0.02 & & 0.01 & 0.12 & 0.01 & & 0.03 & 0.08 & 0.02 \\
\hline Conscientiousness & & 0.29 & 0.06 & $0.17^{\mathrm{c}}$ & & -0.02 & 0.11 & -0.01 & & 0.37 & 0.07 & $0.22^{\mathrm{c}}$ \\
\hline Extraversion & & -0.07 & 0.04 & -0.05 & & 0.05 & 0.08 & 0.05 & & -0.1 & 0.05 & -0.08 \\
\hline Agreeableness & & -0.07 & 0.06 & -0.04 & & 0.03 & 0.13 & 0.02 & & -0.08 & 0.07 & -0.05 \\
\hline Neuroticism & & -0.05 & 0.05 & -0.04 & & 0.09 & 0.1 & 0.06 & & -0.07 & 0.06 & -0.05 \\
\hline
\end{tabular}


B12 - Sample B, All Phyiscs Students Aggregated by Course

\begin{tabular}{|c|c|c|c|c|c|c|c|c|}
\hline \multirow[t]{2}{*}{ Models } & \multicolumn{4}{|c|}{ Pooled Physics 111 Students } & \multicolumn{4}{|c|}{ Pooled Physics 112 Students } \\
\hline & $\mathbf{R}^{2}$ & B & SE & $\beta$ & $\mathbf{R}^{2}$ & B & SE & $\beta$ \\
\hline M1 & 0.15 & & & & 0.20 & & & \\
\hline ACTSATMath & & 0.02 & 0.00 & $0.26^{\mathrm{c}}$ & & 0.01 & 0.00 & $0.24^{\mathrm{c}}$ \\
\hline ACTSATVerb & & 0.01 & 0.00 & 0.16 & & 0.01 & 0.00 & $0.25^{\mathrm{c}}$ \\
\hline M2 & 0.05 & & & & 0.05 & & & \\
\hline Openness & & 0.03 & 0.09 & 0.02 & & 0.16 & 0.09 & 0.09 \\
\hline Conscientiousness & & 0.39 & 0.09 & $0.23^{\mathrm{c}}$ & & 0.32 & 0.08 & $0.21^{\mathrm{c}}$ \\
\hline Extraversion & & -0.12 & 0.06 & -0.09 & & -0.12 & 0.06 & -0.1 \\
\hline Agreeableness & & -0.12 & 0.09 & -0.07 & & -0.06 & 0.08 & -0.04 \\
\hline Neuroticism & & -0.01 & 0.07 & -0.01 & & -0.04 & 0.06 & -0.03 \\
\hline M3 & 0.15 & & & & 0.18 & & & \\
\hline HSGPA & & 0.83 & 0.09 & $0.38^{\mathrm{c}}$ & & 0.87 & 0.09 & $0.43^{\mathrm{c}}$ \\
\hline M4 & 0.20 & & & & 0.26 & & & \\
\hline HSGPA & & 0.57 & 0.10 & $0.26^{\mathrm{c}}$ & & 0.56 & 0.10 & $0.28^{\mathrm{c}}$ \\
\hline ACTSATMath & & 0.01 & 0.00 & $0.21^{\mathrm{c}}$ & & 0.01 & 0.00 & 0.15 \\
\hline ACTSATVerb & & 0.00 & 0.00 & 0.07 & & 0.01 & 0.00 & $0.19^{\mathrm{c}}$ \\
\hline M5 & 0.18 & & & & 0.24 & & & \\
\hline ACTSATMath & & 0.02 & 0.00 & $0.27^{\mathrm{c}}$ & & 0.02 & 0.00 & $0.26^{\mathrm{C}}$ \\
\hline ACTSATVerb & & 0.01 & 0.00 & 0.14 & & 0.01 & 0.00 & $0.23^{\mathrm{c}}$ \\
\hline Openness & & -0.01 & 0.08 & 0 & & 0.05 & 0.08 & 0.03 \\
\hline Conscientiousness & & 0.36 & 0.08 & $0.21^{\mathrm{c}}$ & & 0.31 & 0.07 & $0.21^{\mathrm{c}}$ \\
\hline Extraversion & & -0.1 & 0.06 & -0.07 & & -0.03 & 0.05 & -0.03 \\
\hline Agreeableness & & -0.05 & 0.08 & -0.03 & & 0.00 & 0.07 & 0.00 \\
\hline Neuroticism & & 0.02 & 0.06 & 0.01 & & -0.03 & 0.05 & -0.02 \\
\hline M6 & 0.17 & & & & 0.22 & & & \\
\hline HSGPA & & 0.78 & 0.09 & $0.36^{\mathrm{c}}$ & & 0.85 & 0.09 & $0.42^{\mathrm{c}}$ \\
\hline Openness & & 0.03 & 0.08 & 0.02 & & 0.18 & 0.08 & 0.10 \\
\hline Conscientiousness & & 0.25 & 0.08 & 0.15 & & 0.25 & 0.07 & $0.17^{\mathrm{c}}$ \\
\hline Extraversion & & -0.1 & 0.06 & -0.08 & & -0.07 & 0.05 & -0.06 \\
\hline Agreeableness & & -0.12 & 0.08 & -0.07 & & -0.1 & 0.07 & -0.06 \\
\hline Neuroticism & & -0.08 & 0.06 & -0.05 & & -0.08 & 0.06 & -0.07 \\
\hline M7 & 0.22 & & & & 0.29 & & & \\
\hline HSGPA & & 0.50 & 0.10 & $0.23^{\mathrm{c}}$ & & 0.53 & 0.10 & $0.26^{\mathrm{C}}$ \\
\hline ACTSATMath & & 0.01 & 0.00 & $0.21^{\mathrm{c}}$ & & 0.01 & 0.00 & 0.17 \\
\hline ACTSATVerb & & 0.00 & 0.00 & 0.07 & & 0.01 & 0.00 & 0.18 \\
\hline Openness & & 0.01 & 0.08 & 0.01 & & 0.09 & 0.08 & 0.05 \\
\hline Conscientiousness & & 0.28 & 0.08 & $0.16^{\mathrm{c}}$ & & 0.27 & 0.07 & $0.18^{\mathrm{c}}$ \\
\hline Extraversion & & -0.09 & 0.06 & -0.07 & & -0.03 & 0.05 & -0.03 \\
\hline Agreeableness & & -0.07 & 0.08 & -0.04 & & -0.04 & 0.07 & -0.03 \\
\hline Neuroticism & & -0.03 & 0.06 & -0.02 & & -0.06 & 0.05 & -0.05 \\
\hline
\end{tabular}


B13 - Sample B, Split by Gender

\begin{tabular}{|c|c|c|c|c|c|c|c|c|c|c|c|c|c|c|c|c|}
\hline \multirow[t]{3}{*}{ Models } & \multicolumn{8}{|c|}{ Female Students } & \multicolumn{8}{|c|}{ Male Students } \\
\hline & \multicolumn{4}{|c|}{ Pooled Physics 111} & \multicolumn{4}{|c|}{ Pooled Physics 112} & \multicolumn{4}{|c|}{ Pooled Physics 111} & \multicolumn{4}{|c|}{ Pooled Physics 112} \\
\hline & $\mathbf{R}^{2}$ & B & SE & $\beta$ & $\mathbf{R}^{2}$ & B & SE & $\beta$ & $\mathbf{R}^{2}$ & B & SE & $\beta$ & $\mathbf{R}^{2}$ & B & SE & $\beta$ \\
\hline M1 & 0.16 & & & & 0.40 & & & & \begin{tabular}{|l|l|}
0.14 \\
\end{tabular} & & & & 0.16 & & & \\
\hline ACTSATMath & & 0.01 & 0.01 & 0.08 & & 0.02 & 0.01 & $0.40^{\mathrm{a}}$ & & 0.02 & 0.01 & $0.25^{\mathrm{c}}$ & & 0.01 & 0.00 & $0.20 \mathrm{c}$ \\
\hline ACTSATVerb & & 0.02 & 0.01 & 0.30 & & 0.01 & 0.01 & 0.22 & & 0.00 & 0.00 & 0.08 & & 0.01 & 0.00 & $0.20 \mathrm{c}$ \\
\hline M2 & 0.02 & & & & 0.07 & & & & 0.06 & & & & 0.08 & & & \\
\hline Openness & & -0.03 & 0.23 & -0.02 & & 0.16 & 0.27 & 0.10 & & -0.03 & 0.14 & -0.02 & & 0.13 & 0.13 & 0.07 \\
\hline Conscientiousness & & 0.18 & 0.22 & 0.11 & & 0.33 & 0.22 & 0.23 & & 0.48 & 0.14 & $0.24^{\mathrm{c}}$ & & 0.38 & 0.12 & $0.24^{\mathrm{b}}$ \\
\hline Extraversion & & 0.03 & 0.16 & 0.02 & & 0.07 & 0.2 & 0.06 & & -0.09 & 0.1 & -0.06 & & -0.21 & 0.09 & $-0.18^{\mathrm{a}}$ \\
\hline Agreeableness & & -0.13 & 0.26 & -0.07 & & -0.19 & 0.27 & -0.12 & & -0.21 & 0.13 & -0.11 & & -0.19 & 0.11 & -0.13 \\
\hline Neuroticism & & 0.10 & 0.21 & 0.07 & & 0.12 & 0.20 & 0.09 & & 0.04 & 0.11 & 0.02 & & -0.2 & 0.09 & $-0.16^{\mathrm{a}}$ \\
\hline M3 & 0.27 & & & & 0.38 & & & & 0.13 & & & & 0.15 & & & \\
\hline HSGPA & & 1.43 & 0.27 & $0.52^{\mathrm{c}}$ & & 1.45 & 0.25 & $0.63^{\mathrm{c}}$ & & 0.58 & 0.14 & $0.26^{\mathrm{c}}$ & & 0.75 & 0.12 & $0.40^{\mathrm{c}}$ \\
\hline M4 & 0.32 & & & & 0.56 & & & & \begin{tabular}{|l|}
0.18 \\
\end{tabular} & & & & 0.20 & & & \\
\hline HSGPA & & 1.28 & 0.32 & $0.46^{\mathrm{c}}$ & & 1.26 & 0.26 & $0.55^{\mathrm{c}}$ & & 0.35 & 0.15 & $0.16^{\mathrm{a}}$ & & 0.54 & 0.13 & $0.29 \mathrm{c}$ \\
\hline ACTSATMath & & 0.01 & 0.01 & 0.13 & & 0.00 & 0.01 & 0.03 & & 0.01 & 0.00 & $0.20^{\mathrm{b}}$ & & 0.01 & 0.00 & 0.10 \\
\hline ACTSATVerb & & 0.00 & 0.01 & 0.02 & & 0.01 & 0.01 & $0.37^{\mathrm{b}}$ & & 0.00 & 0.00 & 0.04 & & 0.01 & 0.00 & 0.14 \\
\hline M5 & 0.18 & & & & 0.44 & & & & \begin{tabular}{|l|}
0.19 \\
\end{tabular} & & & & 0.22 & & & \\
\hline ACTSATMath & & 0.01 & 0.01 & 0.08 & & 0.03 & 0.01 & $0.43^{\mathrm{a}}$ & & 0.02 & 0.01 & $0.25^{\mathrm{c}}$ & & 0.01 & 0.00 & $0.23^{\mathrm{b}}$ \\
\hline ACTSATVerb & & 0.02 & 0.01 & 0.30 & & 0.01 & \begin{tabular}{|l|}
0.01 \\
\end{tabular} & 0.16 & & 0.00 & 0.00 & 0.08 & & 0.01 & 0.00 & $0.19^{\mathrm{a}}$ \\
\hline Openness & & -0.03 & 0.22 & -0.02 & & 0.04 & 0.24 & 0.02 & & -0.07 & 0.13 & -0.03 & & 0.05 & 0.12 & 0.02 \\
\hline Conscientiousness & & 0.07 & 0.22 & 0.05 & & 0.17 & 0.19 & 0.12 & & 0.47 & 0.13 & $0.24^{\mathrm{c}}$ & & 0.41 & 0.11 & $0.26^{\mathrm{c}}$ \\
\hline Extraversion & & 0.05 & 0.16 & 0.05 & & 0.09 & 0.17 & 0.08 & & -0.11 & 0.09 & -0.08 & & -0.12 & 0.08 & -0.10 \\
\hline Agreeableness & & -0.05 & 0.24 & -0.03 & & 0.04 & 0.24 & 0.03 & & -0.12 & 0.12 & -0.06 & & -0.11 & 0.10 & -0.07 \\
\hline Neuroticism & & 0.03 & 0.21 & 0.02 & & 0.20 & 0.17 & 0.16 & & 0.08 & 0.11 & 0.05 & & -0.15 & 0.09 & -0.12 \\
\hline M6 & 0.28 & & & & 0.38 & & & & 0.16 & & & & 0.21 & & & \\
\hline HSGPA & & 1.55 & 0.30 & $0.56^{\mathrm{c}}$ & & 1.43 & 0.28 & $0.62^{\mathrm{c}}$ & & 0.53 & 0.14 & $0.24^{\mathrm{c}}$ & & 0.71 & 0.11 & $0.38^{\mathrm{c}}$ \\
\hline Openness & & 0.06 & 0.20 & 0.03 & & 0.11 & 0.22 & 0.06 & & -0.01 & 0.13 & -0.01 & & 0.15 & 0.12 & 0.08 \\
\hline Conscientiousness & & -0.2 & 0.21 & -0.13 & & 0.00 & 0.19 & 0.00 & & 0.39 & 0.14 & $0.20^{\mathrm{b}}$ & & 0.32 & 0.11 & $0.21 \mathrm{~b}$ \\
\hline Extraversion & & 0.04 & 0.14 & 0.04 & & 0.08 & 0.16 & 0.06 & & -0.11 & 0.1 & -0.07 & & -0.17 & 0.08 & $-0.15^{\mathrm{a}}$ \\
\hline Agreeableness & & 0.14 & 0.23 & 0.08 & & -0.03 & 0.22 & -0.02 & & -0.2 & 0.12 & -0.11 & & -0.18 & 0.10 & -0.12 \\
\hline Neuroticism & & -0.01 & 0.18 & -0.01 & & 0.12 & 0.16 & 0.10 & & 0.00 & 0.11 & 0.00 & & -0.19 & 0.09 & $-0.15^{\mathrm{a}}$ \\
\hline M7 & 0.32 & & & & 0.57 & & & & 0.22 & & & & 0.26 & & & \\
\hline HSGPA & & 1.38 & 0.35 & $0.50^{\mathrm{c}}$ & & 1.24 & 0.29 & $0.54^{\mathrm{c}}$ & & 0.27 & 0.15 & 0.12 & & 0.49 & 0.13 & $0.26^{\mathrm{c}}$ \\
\hline ACTSATMath & & 0.01 & 0.01 & 0.11 & & 0.00 & 0.01 & 0.05 & & 0.02 & 0.01 & $0.21^{\mathrm{b}}$ & & 0.01 & 0.00 & 0.13 \\
\hline ACTSATVerb & & 0.00 & 0.01 & 0.03 & & 0.01 & 0.01 & $0.36^{\mathrm{a}}$ & & 0.00 & 0.00 & 0.05 & & 0.01 & 0.00 & 0.13 \\
\hline Openness & & 0.06 & 0.2 & 0.03 & & -0.08 & 0.21 & -0.05 & & -0.05 & 0.13 & -0.02 & & 0.09 & 0.12 & 0.05 \\
\hline Conscientiousness & & -0.18 & 0.21 & -0.11 & & -0.03 & 0.17 & -0.02 & & 0.43 & 0.14 & $0.22^{\mathrm{b}}$ & & 0.36 & 0.11 & $0.23^{\mathrm{c}}$ \\
\hline Extraversion & & 0.04 & 0.14 & 0.04 & & 0.08 & 0.14 & 0.07 & & -0.12 & 0.09 & -0.08 & & -0.13 & 0.08 & -0.11 \\
\hline Agreeableness & & 0.14 & 0.23 & 0.07 & & 0.06 & 0.2 & 0.04 & & -0.13 & 0.12 & -0.07 & & -0.13 & 0.1 & -0.09 \\
\hline Neuroticism & & -0.01 & 0.19 & 0.00 & & 0.13 & 0.15 & 0.1 & & 0.06 & 0.11 & 0.04 & & -0.16 & 0.09 & -0.13 \\
\hline
\end{tabular}


B14 - Sample C, All Physics Students, Disaggregated by Semester and Course

\begin{tabular}{|c|c|c|c|c|c|c|c|c|c|c|c|c|c|c|c|c|}
\hline \multirow{3}{*}{ Models } & \multicolumn{8}{|c|}{ Spring 15} & \multicolumn{8}{|c|}{ Fall 15} \\
\hline & \multicolumn{4}{|c|}{ Physics 111 Students } & \multicolumn{4}{|c|}{ Physics 112 Students } & \multicolumn{4}{|c|}{ Physics 111 Students } & \multicolumn{4}{|c|}{ Physics 112 Students } \\
\hline & $\mathbf{R}^{2}$ & B & SE & $\beta$ & $\mathbf{R}^{2}$ & B & SE & $\beta$ & $\mathbf{R}^{2}$ & B & SE & $\beta$ & $\mathbf{R}^{2}$ & B & SE & $\beta$ \\
\hline M1 & 0.13 & & & & 0.17 & & & & 0.11 & & & & 0.22 & & & \\
\hline ACTSATMath & & 0.02 & 0.01 & $0.26 \mathrm{c}$ & & 0.01 & 0.01 & 0.22 & & 0.02 & 0.01 & 0.21 & & 0.02 & 0.01 & $0.27 \mathrm{c}$ \\
\hline ACTSATVerb & & 0.01 & 0.00 & 0.14 & & 0.01 & 0.00 & 0.24 & & 0.01 & 0.00 & 0.16 & & 0.01 & 0.00 & 0.24 \\
\hline M2 & 0.02 & & & & 0.10 & & & & 0.03 & & & & 0.09 & & & \\
\hline Openness & & -0.05 & 0.10 & -0.03 & & 0.16 & 0.14 & 0.09 & & 0.13 & 0.16 & 0.06 & & 0.16 & 0.11 & 0.10 \\
\hline Conscientiousness & & 0.47 & 0.09 & $0.33 \mathrm{c}$ & & 0.47 & 0.13 & $0.31 \mathrm{c}$ & & 0.23 & 0.17 & 0.11 & & 0.22 & 0.10 & 0.15 \\
\hline Extraversion & & -0.17 & 0.07 & -0.15 & & -0.18 & 0.10 & -0.15 & & -0.04 & 0.12 & -0.03 & & -0.07 & 0.08 & -0.06 \\
\hline Agreeableness & & -0.02 & 0.10 & -0.01 & & -0.04 & 0.12 & -0.03 & & -0.25 & 0.15 & -0.13 & & -0.11 & 0.11 & -0.07 \\
\hline Neuroticism & & -0.02 & 0.08 & -0.01 & & -0.04 & 0.10 & -0.03 & & 0.06 & 0.12 & 0.04 & & -0.04 & 0.07 & -0.04 \\
\hline M3 & 0.20 & & & & 0.16 & & & & 0.08 & & & & 0.19 & & & \\
\hline HSGPA & & 0.91 & 0.11 & $0.44 \mathrm{c}$ & & 0.80 & 0.13 & $0.41 \mathrm{c}$ & & 0.63 & 0.16 & $0.28 \mathrm{c}$ & & 0.94 & 0.12 & $0.44 \mathrm{c}$ \\
\hline M4 & 0.22 & & & & 0.23 & & & & 0.13 & & & & 0.28 & & & \\
\hline HSGPA & & 0.72 & 0.12 & $0.35 \mathrm{c}$ & & 0.56 & 0.14 & $0.28 \mathrm{c}$ & & 0.39 & 0.17 & 0.17 & & 0.60 & 0.13 & $0.28 \mathrm{c}$ \\
\hline ACTSATMath & & 0.01 & 0.01 & 0.18 & & 0.01 & 0.01 & 0.10 & & 0.01 & 0.01 & 0.19 & & 0.01 & 0.01 & 0.21 \\
\hline ACTSATVerb & & 0.00 & 0.00 & 0.02 & & 0.01 & 0.00 & 0.22 & & 0.01 & 0.00 & 0.10 & & 0.01 & 0.00 & 0.15 \\
\hline M5 & 0.13 & & & & & & & & 0.24 & & & & 0.27 & & & \\
\hline ACTSATMath & & 0.02 & 0.01 & $0.24 \mathrm{c}$ & & 0.01 & 0.01 & 0.24 & & 0.02 & 0.01 & 0.23 & & 0.02 & 0.01 & $0.29 \mathrm{c}$ \\
\hline ACTSATVerb & & 0.01 & 0.00 & 0.13 & & 0.01 & 0.00 & 0.23 & & 0.01 & 0.00 & 0.14 & & 0.01 & 0.00 & 0.22 \\
\hline Openness & & -0.08 & 0.09 & -0.05 & & 0.05 & 0.13 & 0.03 & & 0.10 & 0.15 & 0.05 & & 0.03 & 0.10 & 0.02 \\
\hline Conscientiousness & & 0.42 & 0.08 & $0.29 \mathrm{c}$ & & 0.48 & 0.11 & $0.31 \mathrm{c}$ & & 0.25 & 0.16 & 0.12 & & 0.20 & 0.09 & 0.14 \\
\hline Extraversion & & -0.12 & 0.06 & -0.11 & & -0.12 & 0.09 & -0.10 & & -0.07 & 0.11 & -0.05 & & 0.01 & 0.07 & 0.01 \\
\hline Agreeableness & & 0.01 & 0.09 & 0.01 & & 0.01 & 0.11 & 0.00 & & -0.15 & 0.15 & -0.08 & & -0.02 & 0.10 & -0.01 \\
\hline Neuroticism & & -0.02 & 0.07 & -0.01 & & -0.06 & 0.09 & -0.04 & & 0.09 & 0.12 & 0.06 & & 0.00 & 0.07 & 0.00 \\
\hline M6 & 0.25 & & & & 0.24 & & & & 0.09 & & & & 0.22 & & & \\
\hline HSGPA & & 0.81 & 0.11 & $0.39 \mathrm{c}$ & & 0.77 & 0.13 & $0.39 \mathrm{c}$ & & 0.62 & 0.16 & $0.28 \mathrm{c}$ & & 0.97 & 0.13 & $0.45 \mathrm{c}$ \\
\hline Openness & & -0.05 & 0.09 & -0.03 & & 0.23 & 0.13 & 0.12 & & 0.15 & 0.16 & 0.07 & & 0.13 & 0.10 & 0.08 \\
\hline Conscientiousness & & 0.34 & 0.08 & $0.23 \mathrm{c}$ & & 0.38 & 0.12 & 0.24 & & 0.11 & 0.17 & 0.05 & & 0.18 & 0.09 & 0.12 \\
\hline Extraversion & & -0.12 & 0.06 & -0.11 & & -0.20 & 0.09 & \begin{tabular}{|l|}
-0.17 \\
\end{tabular} & & -0.07 & 0.11 & -0.05 & & 0.03 & 0.07 & 0.02 \\
\hline Agreeableness & & -0.03 & 0.09 & -0.02 & & -0.03 & 0.11 & -0.02 & & -0.23 & 0.15 & -0.12 & & -0.19 & 0.10 & -0.13 \\
\hline Neuroticism & & -0.06 & 0.07 & -0.05 & & -0.06 & 0.09 & -0.05 & & -0.04 & 0.12 & -0.02 & & -0.1 & 0.07 & -0.09 \\
\hline M7 & 0.28 & & & & 0.31 & & & & 0.15 & & & & 0.30 & & & \\
\hline HSGPA & & 0.62 & 0.12 & $0.30 \mathrm{c}$ & & 0.48 & 0.14 & $0.24 \mathrm{c}$ & & 0.36 & 0.18 & 0.16 & & 0.63 & 0.14 & 0.30 \\
\hline ACTSATMath & & 0.01 & 0.01 & 0.17 & & 0.01 & 0.01 & \begin{tabular}{|l|}
0.13 \\
\end{tabular} & & 0.01 & 0.01 & 0.20 & & 0.01 & 0.01 & 0.21 \\
\hline ACTSATVerb & & 0.00 & 0.00 & 0.03 & & 0.01 & 0.00 & 0.20 & & 0.01 & 0.00 & 0.09 & & 0.01 & 0.00 & 0.15 \\
\hline Openness & & -0.06 & 0.09 & -0.04 & & 0.12 & 0.13 & 0.06 & & 0.12 & 0.15 & 0.06 & & 0.05 & 0.10 & 0.03 \\
\hline Conscientiousness & & 0.34 & 0.08 & $0.23 \mathrm{c}$ & & 0.41 & 0.11 & $0.27 \mathrm{c}$ & & 0.18 & 0.16 & 0.09 & & 0.18 & 0.09 & $0.12 \mathrm{c}$ \\
\hline Extraversion & & -0.11 & 0.06 & -0.10 & & -0.15 & 0.09 & \begin{tabular}{|l|}
-0.12 \\
\end{tabular} & & -0.08 & 0.11 & -0.05 & & 0.05 & 0.07 & 0.04 \\
\hline Agreeableness & & -0.01 & 0.09 & -0.01 & & 0.00 & 0.10 & 0.00 & & -0.16 & 0.15 & -0.09 & & -0.10 & 0.09 & -0.07 \\
\hline Neuroticism & & -0.05 & 0.07 & -0.04 & & -0.07 & 0.09 & -0.05 & & 0.03 & 0.12 & 0.02 & & -0.05 & 0.07 & -0.04 \\
\hline
\end{tabular}


B15 - Sample C, Female Students

\begin{tabular}{|c|c|c|c|c|c|c|c|c|c|c|c|c|c|c|c|c|}
\hline \multirow{3}{*}{ Models } & \multicolumn{8}{|c|}{ Spring 15} & \multicolumn{8}{|c|}{ Fall 15} \\
\hline & \multicolumn{4}{|c|}{$\begin{array}{l}\text { Physics } 111 \\
\text { Students }\end{array}$} & \multicolumn{4}{|c|}{$\begin{array}{l}\text { Physics 112 } \\
\text { Students }\end{array}$} & \multicolumn{4}{|c|}{$\begin{array}{l}\text { Physics } 111 \\
\text { Students }\end{array}$} & \multicolumn{4}{|c|}{ Physics 112 Students } \\
\hline & $\mathbf{R}^{2}$ & B & SE & $\beta$ & $\mathbf{R}^{2}$ & B & SE & $\beta$ & $\mathbf{R}^{2}$ & B & SE & $\beta$ & $\mathbf{R}^{2}$ & B & SE & $\beta$ \\
\hline M1 & 0.14 & & & & 0.38 & & & & 0.18 & & & & 0.46 & & & \\
\hline ACTSATMath & & 0.02 & 0.01 & 0.28 & & 0.03 & 0.01 & $0.48^{\mathrm{b}}$ & & 0.00 & 0.02 & 0.01 & & 0.02 & 0.01 & $0.33^{\mathrm{b}}$ \\
\hline ACTSATVerb & & 0.01 & 0.01 & 0.11 & & 0.01 & 0.01 & 0.19 & & 0.02 & 0.01 & 0.42 & & 0.02 & 0.01 & $0.40^{\mathrm{b}}$ \\
\hline M2 & 0.09 & & & & 0.12 & & & & 0.04 & & & & 0.13 & & & \\
\hline Openness & & 0.03 & 0.19 & 0.02 & & 0.22 & 0.33 & 0.13 & & 0.12 & 0.33 & 0.06 & & 0.12 & 0.22 & 0.08 \\
\hline Conscientiousness & & 0.43 & 0.18 & $0.32^{\mathrm{a}}$ & & 0.44 & 0.29 & 0.30 & & -0.06 & 0.32 & -0.03 & & -0.02 & 0.21 & -0.01 \\
\hline Extraversion & & -0.12 & 0.13 & -0.12 & & -0.11 & 0.23 & -0.10 & & 0.02 & 0.23 & 0.02 & & 0.11 & 0.15 & 0.10 \\
\hline Agreeableness & & -0.09 & 0.22 & -0.06 & & -0.36 & 0.32 & -0.22 & & -0.27 & 0.34 & -0.14 & & 0.07 & 0.23 & 0.04 \\
\hline Neuroticism & & 0.06 & 0.18 & 0.04 & & 0.00 & 0.25 & 0.00 & & 0.11 & 0.33 & 0.07 & & 0.46 & 0.18 & $0.38^{\mathrm{b}}$ \\
\hline M3 & 0.25 & & & & 0.42 & & & & 0.34 & & & & 0.36 & & & \\
\hline HSGPA & & 1.19 & 0.25 & $0.50^{\mathrm{c}}$ & & 1.48 & 0.30 & $0.65^{\mathrm{c}}$ & & \begin{tabular}{|l}
1.83 \\
\end{tabular} & 0.39 & $0.59^{\mathrm{c}}$ & & 1.47 & 0.28 & $0.60^{\mathrm{c}}$ \\
\hline M4 & 0.29 & & & & 0.56 & & & & 0.36 & & & & \begin{tabular}{|l|}
0.57 \\
\end{tabular} & & & \\
\hline HSGPA & & 1.07 & 0.28 & $0.44^{\mathrm{c}}$ & & 1.16 & 0.32 & $0.51^{\mathrm{c}}$ & & \begin{tabular}{|l}
1.59 \\
\end{tabular} & 0.48 & $0.51^{\mathrm{b}}$ & & 0.90 & 0.26 & $0.37^{\mathrm{c}}$ \\
\hline ACTSATMath & & 0.02 & 0.01 & 0.28 & & 0.01 & 0.01 & 0.15 & & 0.00 & 0.01 & 0.05 & & 0.02 & 0.01 & 0.20 \\
\hline ACTSATVerb & & -0.01 & 0.01 & -0.11 & & 0.01 & 0.01 & 0.29 & & 0.01 & 0.01 & 0.10 & & 0.02 & 0.01 & $0.34^{\mathrm{a}}$ \\
\hline M5 & 0.20 & & & & 0.40 & & & & 0.20 & & & & 0.54 & & & \\
\hline ACTSATMath & & 0.02 & 0.01 & 0.28 & & 0.03 & 0.01 & $0.49^{\mathrm{a}}$ & & 0.00 & 0.02 & 0.01 & & 0.02 & 0.01 & 0.26 \\
\hline ACTSATVerb & & 0.00 & 0.01 & 0.08 & & 0.00 & 0.01 & 0.12 & & 0.02 & 0.02 & 0.42 & & 0.02 & 0.01 & $0.44^{\mathrm{b}}$ \\
\hline Openness & & -0.05 & 0.19 & -0.03 & & 0.12 & 0.32 & 0.07 & & 0.22 & 0.31 & 0.11 & & -0.04 & 0.17 & -0.02 \\
\hline Conscientiousness & & 0.37 & 0.17 & $0.27^{\mathrm{a}}$ & & 0.21 & 0.25 & 0.15 & & -0.03 & 0.3 & -0.02 & & 0.07 & 0.15 & 0.05 \\
\hline Extraversion & & -0.13 & 0.13 & -0.13 & & -0.03 & 0.19 & -0.02 & & 0.08 & 0.22 & 0.06 & & 0.04 & 0.11 & 0.04 \\
\hline Agreeableness & & -0.03 & 0.21 & -0.02 & & -0.08 & 0.28 & -0.05 & & -0.07 & 0.33 & -0.04 & & 0.03 & 0.17 & 0.02 \\
\hline Neuroticism & & 0.02 & 0.17 & 0.01 & & 0.10 & 0.22 & 0.08 & & 0.10 & 0.31 & 0.06 & & 0.33 & 0.14 & $0.27^{\mathrm{a}}$ \\
\hline M6 & 0.28 & & & & 0.45 & & & & 0.38 & & & & 0.42 & & & \\
\hline HSGPA & & 1.11 & 0.26 & $0.46^{\mathrm{c}}$ & & 1.50 & 0.36 & $0.66^{\mathrm{c}}$ & & 1.94 & 0.43 & $0.62^{c}$ & & 1.37 & 0.28 & $0.56^{\mathrm{c}}$ \\
\hline Openness & & 0.08 & 0.17 & 0.05 & & 0.29 & 0.27 & 0.17 & & 0.21 & 0.27 & 0.11 & & 0.15 & 0.18 & 0.11 \\
\hline Conscientiousness & & 0.23 & 0.17 & 0.17 & & -0.05 & 0.26 & -0.04 & & -0.28 & 0.27 & -0.15 & & 0.06 & 0.17 & 0.04 \\
\hline Extraversion & & -0.11 & 0.12 & -0.11 & & -0.08 & 0.18 & -0.07 & & 0.11 & 0.19 & 0.08 & & 0.09 & 0.13 & 0.08 \\
\hline Agreeableness & & 0.01 & 0.20 & 0.00 & & -0.11 & 0.26 & -0.07 & & 0.11 & 0.29 & 0.06 & & -0.06 & 0.19 & -0.04 \\
\hline Neuroticism & & 0.07 & 0.16 & 0.06 & & 0.01 & 0.20 & 0.01 & & 0.05 & 0.27 & 0.03 & & 0.29 & 0.15 & 0.23 \\
\hline M7 & 0.33 & & & & 0.57 & & & & 0.39 & & & & 0.62 & & & \\
\hline HSGPA & & 1.03 & 0.30 & $0.43 \mathrm{c}$ & & 1.23 & 0.38 & $0.54^{\mathrm{b}}$ & & 1.70 & 0.52 & $0.54^{\mathrm{b}}$ & & 0.81 & 0.26 & $0.33^{\mathrm{b}}$ \\
\hline ACTSATMath & & 0.02 & 0.01 & 0.31 & & 0.01 & 0.01 & 0.15 & & 0.00 & 0.01 & 0.02 & & 0.01 & 0.01 & 0.16 \\
\hline ACTSATVerb & & -0.01 & 0.01 & -0.16 & & 0.01 & 0.01 & 0.28 & & 0.01 & 0.01 & 0.13 & & 0.02 & 0.01 & $0.39^{\mathrm{b}}$ \\
\hline Openness & & 0.08 & 0.18 & 0.05 & & 0.08 & 0.27 & 0.05 & & 0.24 & 0.28 & 0.12 & & 0.01 & 0.15 & 0.01 \\
\hline Conscientiousness & & 0.23 & 0.16 & 0.17 & & -0.10 & 0.24 & -0.07 & & -0.24 & 0.28 & -0.13 & & 0.10 & 0.14 & 0.07 \\
\hline Extraversion & & -0.13 & 0.12 & -0.13 & & -0.03 & 0.17 & -0.03 & & 0.12 & 0.19 & 0.09 & & 0.05 & 0.11 & 0.04 \\
\hline Agreeableness & & 0.02 & 0.19 & 0.01 & & -0.01 & 0.24 & -0.01 & & 0.13 & 0.30 & 0.07 & & -0.04 & 0.16 & -0.03 \\
\hline Neuroticism & & 0.06 & 0.16 & 0.05 & & 0.02 & 0.19 & 0.02 & & 0.05 & 0.27 & 0.03 & & 0.25 & 0.13 & $0.21^{\mathrm{a}}$ \\
\hline
\end{tabular}


B16 - Sample C, Male Students

\begin{tabular}{|c|c|c|c|c|c|c|c|c|c|c|c|c|c|c|c|c|}
\hline \multirow{3}{*}{ Models } & \multicolumn{8}{|c|}{ Spring 15} & \multicolumn{8}{|c|}{ Fall 15} \\
\hline & \multicolumn{4}{|c|}{ Physics 111 Students } & \multicolumn{4}{|c|}{ Physics 112 Students } & \multicolumn{4}{|c|}{$\begin{array}{l}\text { Physics } 111 \\
\text { Students }\end{array}$} & \multicolumn{4}{|c|}{$\begin{array}{l}\text { Physics } 112 \\
\text { Students }\end{array}$} \\
\hline & $\mathbf{R}^{2}$ & B & SE & $\beta$ & $\mathbf{R}^{2}$ & B & SE & $\beta$ & $\mathbf{R}^{2}$ & B & SE & $\beta$ & $\mathbf{R}^{2}$ & B & SE & $\beta$ \\
\hline M1 & 0.13 & & & & 0.14 & & & & 0.10 & & & & 0.17 & & & \\
\hline ACTSATMath & & 0.02 & 0.01 & $0.26^{\mathrm{b}}$ & & 0.01 & 0.01 & 0.16 & & 0.02 & 0.01 & $0.22^{\mathrm{a}}$ & & 0.02 & 0.01 & $0.27^{\mathrm{b}}$ \\
\hline ACTSATVerb & & 0.01 & 0.00 & 0.14 & & 0.01 & 0.00 & $0.25^{\mathrm{b}}$ & & 0.01 & 0.01 & 0.13 & & 0.01 & 0.00 & $0.18^{\mathrm{a}}$ \\
\hline M2 & 0.11 & & & & 0.10 & & & & 0.03 & & & & 0.07 & & & \\
\hline Openness & & -0.07 & 0.12 & -0.04 & & 0.17 & 0.16 & 0.09 & & 0.12 & 0.19 & 0.05 & & 0.22 & 0.13 & 0.13 \\
\hline Conscientiousness & & 0.47 & 0.11 & $0.32^{\mathrm{c}}$ & & 0.46 & 0.14 & 0.29 & & 0.4 & 0.21 & $0.18 \mathrm{c}$ & & 0.21 & 0.11 & 0.14 \\
\hline Extraversion & & -0.18 & 0.08 & $-0.15^{\mathrm{a}}$ & & -0.23 & 0.11 & -0.19 & & -0.05 & 0.14 & -0.04 & & -0.15 & 0.09 & -0.13 \\
\hline Agreeableness & & 0.00 & 0.11 & 0.00 & & -0.03 & 0.13 & $-0.02^{\mathrm{a}}$ & & -0.26 & 0.18 & -0.14 & & -0.16 & 0.12 & -0.10 \\
\hline Neuroticism & & -0.05 & 0.09 & -0.04 & & -0.12 & 0.12 & $-0.09^{b}$ & & 0.05 & 0.15 & 0.03 & & -0.21 & 0.09 & $-0.19^{\mathrm{a}}$ \\
\hline M3 & 0.19 & & & & 0.12 & & & & 0.05 & & & & 0.16 & & & \\
\hline HSGPA & & 0.88 & 0.12 & $0.43^{\mathrm{b}}$ & & 0.69 & 0.15 & $0.35^{\mathrm{c}}$ & & 0.50 & 0.18 & $0.22^{\mathrm{c}}$ & & 0.83 & 0.14 & $0.40^{\mathrm{c}}$ \\
\hline M4 & 0.21 & & & & 0.18 & & & & 0.11 & & & & 0.22 & & & \\
\hline HSGPA & & 0.69 & 0.14 & $0.34^{\mathrm{c}}$ & & 0.46 & 0.16 & $0.23^{\mathrm{b}}$ & & 0.28 & 0.19 & 0.12 & & 0.55 & 0.15 & $0.27^{\mathrm{c}}$ \\
\hline ACTSATMath & & 0.01 & 0.01 & $0.16^{\mathrm{a}}$ & & 0.00 & 0.01 & 0.07 & & 0.01 & 0.01 & 0.20 & & 0.01 & 0.01 & $0.22^{\mathrm{b}}$ \\
\hline ACTSATVerb & & 0.00 & 0.00 & 0.04 & & 0.01 & 0.00 & $0.21^{\mathrm{a}}$ & & 0.01 & 0.01 & $0.11^{\mathrm{a}}$ & & 0.00 & 0.00 & 0.09 \\
\hline M5 & 0.22 & & & & 0.26 & & & & 0.13 & & & & 0.20 & & & \\
\hline ACTSATMath & & 0.02 & 0.01 & $0.23^{\mathrm{b}}$ & & 0.01 & 0.01 & $0.19^{\mathrm{a}}$ & & 0.02 & 0.01 & $0.25^{\mathrm{b}}$ & & 0.02 & 0.01 & $0.27^{\mathrm{b}}$ \\
\hline ACTSATVerb & & 0.01 & 0.00 & 0.13 & & 0.01 & 0.00 & $0.25^{\mathrm{b}}$ & & 0.01 & 0.01 & 0.13 & & 0.01 & 0.00 & 0.15 \\
\hline Openness & & -0.09 & 0.11 & -0.05 & & 0.08 & 0.15 & 0.04 & & 0.07 & 0.19 & 0.03 & & 0.10 & 0.12 & 0.06 \\
\hline Conscientiousness & & 0.43 & 0.1 & $0.29^{\mathrm{c}}$ & & 0.51 & 0.13 & $0.33^{\mathrm{c}}$ & & 0.43 & 0.21 & $0.19^{\mathrm{a}}$ & & 0.20 & 0.11 & 0.14 \\
\hline Extraversion & & -0.11 & 0.08 & -0.09 & & -0.16 & 0.10 & -0.13 & & -0.09 & 0.13 & -0.06 & & -0.05 & 0.08 & -0.04 \\
\hline Agreeableness & & 0.03 & 0.11 & 0.02 & & -0.01 & 0.12 & -0.01 & & -0.16 & 0.17 & -0.08 & & -0.06 & 0.11 & -0.04 \\
\hline Neuroticism & & -0.03 & 0.09 & -0.02 & & -0.12 & 0.11 & -0.09 & & 0.14 & 0.14 & 0.09 & & -0.13 & 0.08 & -0.11 \\
\hline M6 & 0.25 & & & & 0.22 & & & & 0.08 & & & & 0.22 & & & \\
\hline HSGPA & & 0.78 & 0.12 & $0.38^{\mathrm{c}}$ & & 0.67 & 0.14 & $0.34^{\mathrm{c}}$ & & 0.49 & 0.19 & $0.22^{\mathrm{b}}$ & & 0.83 & 0.14 & $0.40^{\mathrm{c}}$ \\
\hline Openness & & -0.1 & 0.11 & -0.06 & & 0.23 & 0.15 & 0.12 & & 0.16 & 0.19 & 0.07 & & 0.18 & 0.12 & 0.10 \\
\hline Conscientiousness & & 0.36 & 0.10 & $0.24^{\mathrm{c}}$ & & 0.42 & 0.13 & 0.27 & & 0.33 & 0.21 & 0.15 & & 0.16 & 0.11 & 0.11 \\
\hline Extraversion & & -0.11 & 0.08 & -0.09 & & -0.23 & 0.11 & $-0.19^{\mathrm{a}}$ & & -0.08 & 0.14 & -0.05 & & -0.03 & 0.08 & -0.03 \\
\hline Agreeableness & & -0.02 & 0.10 & -0.01 & & -0.02 & 0.12 & \begin{tabular}{|l|}
-0.02 \\
\end{tabular} & & -0.27 & 0.18 & -0.14 & & -0.22 & 0.11 & $-0.15^{\mathrm{a}}$ \\
\hline Neuroticism & & -0.06 & 0.09 & -0.05 & & -0.10 & 0.11 & $-0.08^{b}$ & & 0.02 & 0.15 & 0.01 & & -0.22 & 0.08 & $-0.20^{b}$ \\
\hline M7 & 0.28 & & & & 0.28 & & & & 0.14 & & & & 0.26 & & & \\
\hline HSGPA & & 0.59 & 0.14 & $0.29^{\mathrm{c}}$ & & 0.38 & 0.16 & $0.19^{\mathrm{a}}$ & & 0.23 & 0.20 & 0.10 & & 0.60 & 0.16 & $0.29^{\mathrm{c}}$ \\
\hline ACTSATMath & & 0.01 & 0.01 & 0.15 & & 0.01 & 0.01 & 0.12 & & 0.02 & 0.01 & $0.22^{\mathrm{a}}$ & & 0.01 & 0.01 & $0.19^{\mathrm{a}}$ \\
\hline ACTSATVerb & & 0.00 & 0.00 & 0.06 & & 0.01 & 0.00 & $0.21^{\mathrm{a}}$ & & 0.01 & 0.01 & 0.10 & & 0.00 & 0.00 & 0.07 \\
\hline Openness & & -0.10 & 0.11 & -0.06 & & 0.13 & 0.15 & 0.07 & & 0.09 & 0.19 & 0.04 & & 0.12 & 0.12 & 0.07 \\
\hline Conscientiousness & & 0.37 & 0.10 & $0.25^{\mathrm{c}}$ & & 0.48 & 0.13 & $0.31^{\mathrm{c}}$ & & 0.40 & 0.21 & 0.18 & & 0.18 & 0.10 & 0.12 \\
\hline Extraversion & & -0.09 & 0.08 & -0.08 & & -0.18 & 0.10 & -0.14 & & -0.1 & 0.13 & -0.06 & & -0.01 & 0.08 & -0.01 \\
\hline Agreeableness & & 0.00 & 0.10 & 0.00 & & -0.01 & 0.12 & -0.01 & & -0.17 & 0.17 & -0.09 & & -0.14 & 0.11 & -0.10 \\
\hline Neuroticism & & -0.05 & 0.09 & -0.03 & & -0.11 & 0.11 & -0.08 & & 0.12 & 0.15 & 0.07 & & -0.16 & 0.08 & $-0.15^{\mathrm{a}}$ \\
\hline
\end{tabular}




\section{SECTION 3: CHANGES IN $\mathbf{R}^{2}$ RESULTS}

The following set of tables contain the results of the changes in $\mathrm{R}^{2}$ between specific hierarchal linear regression models - models 1 to 5,3 to 6 , and 4 to 7 . Statistical significance denoted by superscripts - "a" $p<0.05$, "b" $p<0.01$, "c" $p<0.001$.

\section{SUBSECTION A: RESEARCH QUESTION 4}

B17 - Sample A

\begin{tabular}{|c|c|c|c|c|c|c|c|c|c|c|}
\hline \multirow[b]{2}{*}{ Gender } & \multirow[b]{2}{*}{ Model } & \multirow[b]{2}{*}{$\mathbf{R}$} & \multirow[b]{2}{*}{$\mathbf{R}^{2}$} & \multirow[b]{2}{*}{$\begin{array}{c}\text { Adjusted } \\
\mathbf{R}^{\mathbf{2}}\end{array}$} & \multirow[b]{2}{*}{$\begin{array}{l}\text { Std. Error of } \\
\text { the Estimate }\end{array}$} & \multicolumn{5}{|c|}{ Change Statistics } \\
\hline & & & & & & $\Delta \mathbf{R}^{2}$ & $\begin{array}{c}\text { F } \\
\text { Change }\end{array}$ & df1 & df 2 & $\begin{array}{c}\text { Sig. F } \\
\text { Change }\end{array}$ \\
\hline \multirow{3}{*}{$\mathbf{F}$} & 1 to 5 & 0.49 & 0.24 & 0.20 & 0.86 & 0.01 & 0.60 & 5 & 160 & 0.70 \\
\hline & 3 to 6 & 0.56 & 0.31 & 0.29 & 0.82 & 0.01 & 0.26 & 5 & 161 & 0.93 \\
\hline & 4 to 7 & 0.61 & 0.38 & 0.34 & 0.78 & 0.00 & 0.22 & 5 & 159 & 0.95 \\
\hline \multirow{3}{*}{$\mathbf{M}$} & 1 to 5 & 0.44 & 0.19 & 0.18 & 0.86 & 0.06 & 8.43 & 5 & 589 & $0.00^{\mathrm{c}}$ \\
\hline & 3 to 6 & 0.42 & 0.17 & 0.17 & 0.87 & 0.05 & 6.43 & 5 & 590 & $0.00^{\mathrm{c}}$ \\
\hline & 4 to 7 & 0.47 & 0.22 & 0.21 & 0.85 & 0.05 & 7.00 & 5 & 588 & $0.00^{\mathrm{c}}$ \\
\hline
\end{tabular}

B18 - Sample B: P111

\begin{tabular}{|c|c|c|c|c|c|c|c|c|c|c|}
\hline \multirow[b]{2}{*}{ Gender } & \multirow[b]{2}{*}{ Model } & \multirow[b]{2}{*}{$\mathbf{R}$} & \multirow[b]{2}{*}{$\mathbf{R}^{2}$} & \multirow{2}{*}{$\begin{array}{l}\text { Adjusted } \\
\qquad \mathbf{R}^{2}\end{array}$} & \multirow{2}{*}{$\begin{array}{l}\text { Std. Error of } \\
\text { the Estimate }\end{array}$} & \multicolumn{5}{|c|}{ Change Statistics } \\
\hline & & & & & & $\Delta \mathbf{R}^{2}$ & $\begin{array}{c}\text { F } \\
\text { Change }\end{array}$ & df1 & df2 & $\begin{array}{c}\text { Sig. F } \\
\text { Change }\end{array}$ \\
\hline \multirow{3}{*}{$\mathbf{F}$} & 1 to 5 & 0.37 & 0.14 & 0.05 & 1.03 & 0.00 & 0.06 & 5 & 70 & 1.00 \\
\hline & 3 to 6 & 0.53 & 0.28 & 0.22 & 0.93 & 0.01 & 0.23 & 5 & 71 & 0.95 \\
\hline & 4 to 7 & 0.55 & 0.30 & 0.22 & 0.94 & 0.01 & 0.19 & 5 & 69 & 0.97 \\
\hline \multirow{3}{*}{$\mathbf{M}$} & 1 to 5 & 0.37 & 0.14 & 0.11 & 1.00 & 0.05 & 2.67 & 5 & 237 & $0.02^{\mathrm{a}}$ \\
\hline & 3 to 6 & 0.32 & 0.11 & 0.08 & 1.02 & 0.04 & 1.93 & 5 & 238 & 0.09 \\
\hline & 4 to 7 & 0.39 & 0.15 & 0.12 & 0.99 & 0.04 & 2.21 & 5 & 236 & 0.06 \\
\hline
\end{tabular}

B19 - Sample B: P112

\begin{tabular}{|c|c|c|c|c|c|c|c|c|c|c|}
\hline \multirow[b]{2}{*}{ Gender } & \multirow[b]{2}{*}{ Model } & \multirow[b]{2}{*}{$\mathbf{R}$} & \multirow[b]{2}{*}{$\mathbf{R}^{2}$} & \multirow{2}{*}{$\underset{\mathbf{R}^{2}}{\text { Adjusted }}$} & \multirow{2}{*}{$\begin{array}{l}\text { Std. Error of } \\
\text { the Estimate }\end{array}$} & \multicolumn{5}{|c|}{ Change Statistics } \\
\hline & & & & & & $\Delta \mathbf{R}^{2}$ & $\begin{array}{c}\text { F } \\
\text { Change }\end{array}$ & df1 & df2 & $\begin{array}{c}\text { Sig. F } \\
\text { Change }\end{array}$ \\
\hline \multirow{3}{*}{$\mathbf{F}$} & 1 to 5 & 0.60 & 0.37 & 0.26 & 0.79 & 0.04 & 0.60 & 5 & 44 & 0.70 \\
\hline & 3 to 6 & 0.65 & 0.42 & 0.34 & 0.75 & 0.02 & 0.26 & 5 & 45 & 0.94 \\
\hline & 4 to 7 & 0.74 & 0.55 & 0.47 & 0.67 & 0.01 & 0.25 & 5 & 43 & 0.94 \\
\hline \multirow{3}{*}{$\mathbf{M}$} & 1 to 5 & 0.46 & 0.22 & 0.19 & 0.82 & 0.08 & 4.39 & 5 & 217 & $0.00^{\mathrm{c}}$ \\
\hline & 3 to 6 & 0.48 & 0.23 & 0.21 & 0.81 & 0.07 & 3.73 & 5 & 218 & $0.00^{\mathrm{c}}$ \\
\hline & 4 to 7 & 0.51 & 0.26 & 0.23 & 0.79 & 0.07 & 3.87 & 5 & 216 & $0.00^{\mathrm{b}}$ \\
\hline
\end{tabular}


B20 - Sample C: Spring 15 P111

\begin{tabular}{|c|c|c|c|c|c|c|c|c|c|c|}
\hline \multirow[b]{2}{*}{ Gender } & \multirow[b]{2}{*}{ Model } & \multirow[b]{2}{*}{$\mathbf{R}$} & \multirow[b]{2}{*}{$\mathbf{R}^{2}$} & \multirow[b]{2}{*}{$\begin{array}{c}\text { Adjusted } \\
\qquad \mathbf{R}^{2}\end{array}$} & \multirow{2}{*}{$\begin{array}{l}\text { Std. Error } \\
\text { of the } \\
\text { Estimate }\end{array}$} & \multicolumn{5}{|c|}{ Change Statistics } \\
\hline & & & & & & $\Delta R^{2}$ & \begin{tabular}{|c|}
$\mathbf{F}$ \\
Change
\end{tabular} & df1 & df2 & $\begin{array}{c}\text { Sig. F } \\
\text { Change }\end{array}$ \\
\hline \multirow{3}{*}{$\mathbf{F}$} & 1 to 5 & 0.45 & 0.20 & 0.12 & 0.82 & 0.07 & 1.05 & 5 & 64 & 0.40 \\
\hline & 3 to 6 & 0.53 & 0.28 & 0.22 & 0.77 & 0.04 & 0.68 & 5 & 65 & 0.64 \\
\hline & 4 to 7 & 0.57 & 0.33 & 0.24 & 0.76 & 0.04 & 0.72 & 5 & 63 & 0.61 \\
\hline \multirow{3}{*}{$\mathbf{M}$} & 1 to 5 & 0.47 & 0.22 & 0.19 & 0.80 & 0.09 & 4.85 & 5 & 216 & $0.00^{\mathrm{c}}$ \\
\hline & 3 to 6 & 0.50 & 0.25 & 0.23 & 0.79 & 0.06 & 3.71 & 5 & 217 & $0.00^{\mathrm{b}}$ \\
\hline & 4 to 7 & 0.53 & 0.28 & 0.25 & 0.78 & 0.06 & 3.78 & 5 & 215 & $0.00^{\mathrm{a}}$ \\
\hline
\end{tabular}

B21 - Sample C: Spring 15 P112

\begin{tabular}{|c|c|c|c|c|c|c|c|c|c|c|}
\hline \multirow[b]{2}{*}{ Gender } & \multirow[b]{2}{*}{ Model } & \multirow[b]{2}{*}{$\mathbf{R}$} & \multirow[b]{2}{*}{$\mathbf{R}^{2}$} & \multirow{2}{*}{$\begin{array}{l}\text { Adjusted } \\
\qquad \mathbf{R}^{2}\end{array}$} & \multirow{2}{*}{$\begin{array}{l}\text { Std. Error of } \\
\text { the Estimate }\end{array}$} & \multicolumn{5}{|c|}{ Change Statistics } \\
\hline & & & & & & $\Delta \mathbf{R}^{2}$ & $\begin{array}{c}\text { F } \\
\text { Change }\end{array}$ & df1 & df2 & $\begin{array}{l}\text { Sig. F } \\
\text { Change }\end{array}$ \\
\hline \multirow{3}{*}{$\mathbf{F}$} & 1 to 5 & 0.63 & 0.40 & 0.25 & 0.80 & 0.02 & 0.22 & 5 & 28 & 0.95 \\
\hline & 3 to 6 & 0.67 & 0.45 & 0.33 & 0.75 & 0.03 & 0.31 & 5 & 29 & 0.91 \\
\hline & 4 to 7 & 0.76 & 0.57 & 0.44 & 0.69 & 0.01 & 0.09 & 5 & 27 & 0.99 \\
\hline \multirow{3}{*}{$\mathbf{M}$} & 1 to 5 & 0.51 & 0.26 & 0.22 & 0.82 & 0.12 & 4.91 & 5 & 153 & $0.00^{\mathrm{c}}$ \\
\hline & 3 to 6 & 0.47 & 0.22 & 0.19 & 0.83 & 0.10 & 3.73 & 5 & 154 & $0.00^{\mathrm{b}}$ \\
\hline & 4 to 7 & 0.53 & 0.28 & 0.25 & 0.80 & 0.11 & 4.48 & 5 & 152 & $0.00^{\mathrm{c}}$ \\
\hline
\end{tabular}

B22 - Sample C: Fall 15 P111

\begin{tabular}{|c|c|c|c|c|c|c|c|c|c|c|}
\hline \multirow[b]{2}{*}{ Gender } & \multirow[b]{2}{*}{ Model } & \multirow[b]{2}{*}{$\mathbf{R}$} & \multirow{2}{*}{$\mathbf{R}^{2}$} & \multirow{2}{*}{$\begin{array}{c}\text { Adjusted } \\
\qquad \mathbf{R}^{2}\end{array}$} & \multirow{2}{*}{$\begin{array}{l}\text { Std. Error of } \\
\text { the Estimate }\end{array}$} & \multicolumn{5}{|c|}{ Change Statistics } \\
\hline & & & & & & $\Delta \mathbf{R}^{2}$ & $\begin{array}{c}\text { F } \\
\text { Change }\end{array}$ & df1 & df2 & $\begin{array}{c}\text { Sig. F } \\
\text { Change }\end{array}$ \\
\hline \multirow{3}{*}{$\mathbf{F}$} & 1 to 5 & 0.45 & 0.20 & 0.05 & 1.13 & 0.03 & \begin{tabular}{|l|} 
\\
0.23
\end{tabular} & 5 & 36 & 0.95 \\
\hline & 3 to 6 & 0.61 & 0.38 & 0.28 & 0.98 & 0.04 & 0.41 & 5 & 37 & 0.84 \\
\hline & 4 to 7 & 0.63 & 0.39 & 0.25 & 1.00 & 0.03 & 0.39 & 5 & 35 & 0.85 \\
\hline \multirow{3}{*}{$\mathbf{M}$} & 1 to 5 & 0.36 & 0.13 & 0.09 & 1.06 & 0.03 & 1.08 & 5 & 140 & 0.38 \\
\hline & 3 to 6 & 0.28 & 0.08 & 0.04 & 1.09 & 0.03 & 0.81 & 5 & 141 & 0.54 \\
\hline & 4 to 7 & 0.37 & 0.14 & 0.09 & 1.06 & 0.03 & 0.94 & 5 & 139 & 0.46 \\
\hline
\end{tabular}

B23 - Sample C: Fall 15 P112

\begin{tabular}{|c|c|c|c|c|c|c|c|c|c|c|}
\hline \multirow{2}{*}{ Gender } & \multirow{2}{*}{ Model } & \multirow{2}{*}{$\mathbf{R}$} & \multirow{2}{*}{$\mathbf{R 2}$} & \multirow{2}{*}{$\begin{array}{c}\text { Adjusted } \\
\text { R2 }\end{array}$} & \multirow{2}{*}{$\begin{array}{l}\text { Std. Error of the } \\
\text { Estimate }\end{array}$} & \multicolumn{5}{|c|}{ Change Statistics } \\
\hline & & & & & & $\Delta \mathrm{R} 2$ & F Change & df1 & df2 & Sig. F Change \\
\hline \multirow{3}{*}{$\mathbf{F}$} & 1 to 5 & 0.73 & 0.54 & 0.47 & 0.63 & 0.08 & 1.50 & 5 & 46 & 0.21 \\
\hline & 3 to 6 & 0.65 & 0.42 & 0.35 & 0.70 & 0.06 & 1.03 & 5 & 47 & 0.41 \\
\hline & 4 to 7 & 0.79 & 0.62 & 0.55 & 0.58 & 0.05 & 1.20 & 5 & 45 & 0.33 \\
\hline \multirow{3}{*}{ M } & 1 to 5 & 0.45 & 0.20 & 0.17 & 0.79 & 0.03 & 1.57 & 5 & 183 & 0.17 \\
\hline & 3 to 6 & 0.47 & 0.22 & 0.19 & 0.78 & 0.06 & 2.89 & 5 & 184 & $0.02 \mathrm{a}$ \\
\hline & 4 to 7 & 0.51 & 0.26 & 0.23 & 0.76 & 0.04 & 1.95 & 5 & 182 & 0.09 \\
\hline
\end{tabular}




\section{SUBSECTION B: RESEARCH QUESTION 5}

B24 - Sample A, Comparing Model 1 to 5, 3 to 6, and 4 to 7

\begin{tabular}{|l|c|c|c|c|c|c|c|c|c|}
\hline & \multirow{2}{*}{ Model } & $\mathbf{R}$ & $\mathbf{R}^{\mathbf{2}}$ & \multirow{2}{*}{$\begin{array}{c}\text { Adjusted } \\
\mathbf{R}^{\mathbf{2}}\end{array}$} & $\begin{array}{c}\text { Std. Error of } \\
\text { the Estimate }\end{array}$ & \multicolumn{4}{|c|}{ Change Statistics } \\
\cline { 6 - 10 } & & & $\mathbf{\Delta R}^{\mathbf{2}}$ & $\begin{array}{c}\mathbf{F} \\
\text { Change }\end{array}$ & $\mathbf{d f 1}$ & $\mathbf{d f 2}$ & $\begin{array}{c}\text { Sig. F } \\
\text { Change }\end{array}$ \\
\hline 1 to 5 & 0.44 & 0.20 & 0.19 & 0.86 & 0.04 & 7.77 & 5 & 757 & $0.00^{\mathrm{c}}$ \\
\hline 3 to 6 & 0.429 & 0.184 & 0.178 & 0.8694 & 0.027 & 5.062 & 5 & 758 & $0.00^{\mathrm{c}}$ \\
\hline 4 to 7 & 0.49 & 0.24 & 0.23 & 0.84 & 0.03 & 5.55 & 5 & 756 & $0.00^{\mathrm{c}}$ \\
\hline
\end{tabular}

B25 - Sample B, Comparing Model 1 to 5, 3 to 6 , and 4 to 7

\begin{tabular}{|c|c|c|c|c|c|c|c|c|c|c|}
\hline \multirow[b]{2}{*}{ Class } & \multirow[b]{2}{*}{ Model } & \multirow[b]{2}{*}{$\mathbf{R}$} & \multirow[b]{2}{*}{$\mathbf{R}^{2}$} & \multirow[b]{2}{*}{$\begin{array}{c}\text { Adjusted } \\
\qquad \mathbf{R}^{2}\end{array}$} & \multirow[b]{2}{*}{$\begin{array}{l}\text { Std. Error of } \\
\text { the Estimate }\end{array}$} & \multicolumn{5}{|c|}{ Change Statistics } \\
\hline & & & & & & $\Delta \mathbf{R}^{2}$ & $\begin{array}{c}\mathbf{F} \\
\text { Change }\end{array}$ & df1 & df2 & $\begin{array}{c}\text { Sig. F } \\
\text { Change }\end{array}$ \\
\hline \multirow{3}{*}{ P111 } & 1 to 5 & 0.37 & 0.13 & 0.11 & 1.00 & 0.03 & 2.43 & 5 & 315 & $0.04^{\mathrm{a}}$ \\
\hline & 3 to 6 & 0.34 & 0.12 & 0.10 & 1.01 & 0.02 & 1.26 & 5 & 316 & 0.28 \\
\hline & 4 to 7 & 0.40 & 0.16 & 0.14 & 0.99 & 0.02 & 1.44 & 5 & 314 & 0.21 \\
\hline \multirow{3}{*}{ P112 } & 1 to 5 & 0.48 & 0.23 & 0.21 & 0.81 & 0.06 & 4.19 & 5 & 269 & $0.00^{\mathrm{c}}$ \\
\hline & 3 to 6 & 0.49 & 0.239 & 0.222 & 0.803 & 0.044 & 3.092 & 5 & 270 & $0.01^{\mathrm{a}}$ \\
\hline & 4 to 7 & 0.54 & 0.29 & 0.27 & 0.78 & 0.04 & 3.29 & 5 & 268 & $0.01^{\mathrm{a}}$ \\
\hline
\end{tabular}

B26 - Sample C, Comparing Model 1 to 5, 3 to 6, and 4 to 7

\begin{tabular}{|c|c|c|c|c|c|c|c|c|c|c|c|}
\hline \multirow{2}{*}{\multicolumn{2}{|c|}{ Class }} & \multirow{3}{*}{\begin{tabular}{|l|} 
Model \\
1 to 5 \\
\end{tabular}} & \multirow{3}{*}{\begin{tabular}{|c|}
$\mathbf{R}$ \\
0.46 \\
\end{tabular}} & \multirow{3}{*}{$\begin{array}{c}\mathbf{R}^{2} \\
0.22\end{array}$} & \multirow{3}{*}{\begin{tabular}{|c}
$\begin{array}{c}\text { Adjusted } \\
\mathbf{R}^{\mathbf{2}}\end{array}$ \\
0.2 \\
\end{tabular}} & \multirow{3}{*}{\begin{tabular}{|c|}
$\begin{array}{c}\text { Std. } \\
\text { Error of } \\
\text { the } \\
\text { Estimate }\end{array}$ \\
0.8 \\
\end{tabular}} & \multicolumn{5}{|c|}{ Change Statistics } \\
\hline & & & & & & & \multirow{2}{*}{$\begin{array}{l}\Delta \mathbf{R}^{2} \\
0.08\end{array}$} & \multirow{2}{*}{\begin{tabular}{|c|}
$\begin{array}{c}\text { F } \\
\text { Change }\end{array}$ \\
5.96 \\
\end{tabular}} & \multirow{2}{*}{$\begin{array}{c}\text { df1 } \\
5\end{array}$} & \multirow{2}{*}{$\begin{array}{l}\mathbf{d f 2} \\
288 \\
\end{array}$} & \multirow{2}{*}{$\begin{array}{c}\begin{array}{c}\text { Sig. F } \\
\text { Change }\end{array} \\
0.00^{\mathrm{c}}\end{array}$} \\
\hline \multirow{6}{*}{ Spring } & & & & & & & & & & & \\
\hline & \multirow[t]{2}{*}{ P111 } & 3 to 6 & 0.5 & 0.25 & 0.23 & 0.78 & 0.06 & 4.21 & 5 & 289 & $0.00^{\mathrm{c}}$ \\
\hline & & 4 to 7 & 0.53 & 0.28 & 0.26 & 0.77 & 0.05 & 4.29 & 5 & 287 & $0.00^{c}$ \\
\hline & \multirow{3}{*}{ P112 } & 1 to 5 & 0.52 & 0.27 & 0.24 & 0.81 & 0.1 & 4.93 & 5 & 189 & $0.00^{\mathrm{c}}$ \\
\hline & & 3 to 6 & 0.49 & 0.24 & 0.22 & 0.82 & 0.08 & 3.75 & 5 & 190 & $0.00^{\mathrm{b}}$ \\
\hline & & 4 to 7 & 0.56 & 0.31 & 0.28 & 0.79 & 0.08 & 4.2 & 5 & 188 & $0.00^{\mathrm{c}}$ \\
\hline \multirow{6}{*}{ Fall } & \multirow{3}{*}{ P111 } & 1 to 5 & 0.36 & 0.13 & 0.1 & 1.07 & 0.02 & 0.77 & 5 & 184 & 0.57 \\
\hline & & 3 to 6 & 0.31 & 0.09 & 0.06 & 1.08 & 0.02 & 0.64 & 5 & 185 & 0.67 \\
\hline & & 4 to 7 & 0.38 & 0.15 & 0.11 & 1.06 & 0.01 & 0.55 & 5 & 183 & 0.74 \\
\hline & \multirow{3}{*}{ P112 } & 1 to 5 & 0.49 & 0.24 & 0.21 & 0.77 & 0.02 & 1.11 & 5 & 237 & 0.36 \\
\hline & & 3 to 6 & 0.47 & 0.22 & 0.2 & 0.78 & 0.03 & 1.91 & 5 & 238 & 0.09 \\
\hline & & 4 to 7 & 0.55 & 0.3 & 0.28 & 0.74 & 0.02 & 1.34 & 5 & 236 & 0.25 \\
\hline
\end{tabular}

